California Western School of Law

CWSL Scholarly Commons

Faculty Scholarship

2020

Disgorging Harvey Weinstein's Salary

Jessica K. Fink

Follow this and additional works at: https://scholarlycommons.law.cwsl.edu/fs

Part of the Civil Rights and Discrimination Commons, Labor and Employment Law Commons, and the Law and Gender Commons 


\section{Disgorging Harvey Weinstein's Salary}

\section{Jessica Fink $\dagger$}

Harvey Weinstein dramatically altered the way that people view sexual harassment in the workplace. Workplace sexual harassment is far from a new phenomenon - with many perpetrators of such harassment (including Weinstein himself) having gotten away with this misbehavior for decades. Yet the exposure of Weinstein's misdeeds opened the floodgates, leading countless women from a variety of work environments to share their own experiences with sexual harassment at work. As the \#MeToo movement has continued to occupy the headlines, workplace harassment has begun to seem as ubiquitous as it is distressing.

This intensified spotlight on sexual harassment has exposed a persistent frustration among academics, the media, and members of the public, as society puzzles over what can be done to eliminate sexual misbehavior at work. Robust research indicates that conventional mechanisms for addressing sexual harassment, like carefully worded policies or mandatory training sessions, fail to root out perpetrators like Weinstein. Instead, research demonstrates that only significant cultural change in the workplace can reduce instances of sexual misconduct. This Article explores a new-and potentially radical-way of instilling such cultural change.

This Article describes a little known but powerful remedies principle known as the faithless servant doctrine, which allows for the disgorgement of compensation from employees who breach their fiduciary duties to their employers. When employees breach their fiduciary duties by creating or perpetuating a culture of workplace harassment, the faithless servant doctrine could provide companies with a powerful tool to demonstrate that this sexual misconduct negates any value that a misbehaving employee otherwise brings to the workplace. This article questions whether using compensation disgorgement

DOI: https://doi.org/10.15779/Z38SB3X01M

$\dagger$. Clara Shortridge Foltz Professor of Law, California Western School of Law. J.D., Harvard Law School, 2001; B.A., University of Michigan, 1997. I am grateful to my colleagues at California Western School of Law for their input regarding this project in its earliest stages, and specifically thank Professor Daniel Yeager for his insights and suggestions throughout this process. Thanks also to Lindsey Cherpes for her excellent and thorough research assistance. 
to hit wrongdoers where it hurts-in their wallets-finally could foster the cultural shift that is necessary to decrease sexual harassment at work.

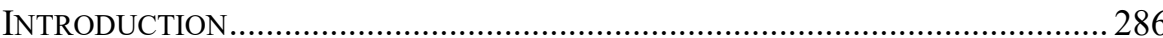

I. HARVEY WEINSTEIN AS A CASE StUdy FOR SEXUAL HARASSMENT

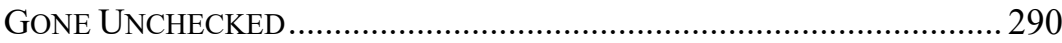

II. MINIMIZING HARASSMENT IN THE WORKPLACE AND BEYOND ................... 294

A. The Inadequacy of Traditional Mechanisms for Countering

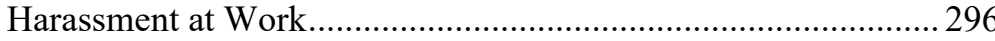

B. The Magic Bullet: Changing the Workplace Culture .................. 297

1. Changing the Workplace Culture by Modeling a Serious, Sober Approach to Workplace Sexual Harassment .............. 299

2. Changing the Workplace Culture by Creating Concrete Negative Ramifications for Misbehavior. 301

3. Changing the Workplace Culture by Altering the Power Structure within an Organization ............................................. 304

III. USING THE FAITHLESS SERVANT DOCTRINE AND OTHER

DISGORGEMENT STRATEGIES TO HIT HARASSERS WHERE IT HURTS (I.E., IN THEIR WALLETS) . 306

A. Astra, USA v. Bildman: A Case Study in the Faithless Servant

Doctrine Applied to the Sexual Harassment Context 309

B. Disgorging Compensation Beyond Astra: Additional

Examples of Compensation Forfeiture 311

1. Cases Applying Compensation Forfeiture to Fiduciary Breaches 312

2. The Varying Contours of Compensation Disgorgement........ 314

a. Differing views regarding the amount of harm that an employer must suffer in order to trigger disgorgement.. 314

b. Differing views regarding the amount of compensation that an employer can disgorge. 317

C. Hitting Harvey Where it Hurts: Harvey Weinstein as a Faithless Servant 320

D. But Who Gets Weinstein's Salary? When the Faithless Servant Works for a Culpable Master. 326

\section{INTRODUCTION}

In the fall of 2017, the world watched in shock, awe, dismay, and vindication as famed producer and movie mogul Harvey Weinstein faced an onslaught of allegations detailing decades of sexual and other misconduct toward 
dozens of women. ${ }^{1}$ Combined with the astonishment and concern, however, was a sense of resignation: Weinstein's misbehavior had been an open secret in Hollywood for years, seen yet largely ignored by dozen - if not hundreds — of individuals both inside and outside of the entertainment industry. ${ }^{2}$ Women had warned each other behind the scenes to avoid vulnerable interactions with the producer; ${ }^{3}$ media outlets had been persuaded to suppress stories of Weinstein's indiscretions. ${ }^{4}$ Allegations regarding Weinstein's sexual misconduct even found their way into the opening monologue of the 2013 Academy Awards. ${ }^{5}$ Yet despite the swirls of allegations against him, Weinstein for years operated almost completely unchecked. ${ }^{6}$

In many ways, the eventual public airing of the charges against Weinstein opened the floodgates for countless women to come forward, not only corroborating stories of Weinstein's misdeeds, but also alleging similar misbehavior by scores of other men, some well-known and some not. ${ }^{7}$ From radio hosts to college professors to businesspeople, men across various industries found themselves accused of a broad range of sexual misbehavior in the workplace. ${ }^{8}$ Women turned to social media to express their collective outrage,

1. See Ronan Farrow, From Aggressive Overtures to Sexual Assault: Harvey Weinstein's Accusers Tell Their Stories, NEw YORKER (Oct. 23, 2017), https://www.newyorker.com/news/newsdesk/from-aggressive-overtures-to-sexual-assault-harvey-weinsteins-accusers-tell-their-stories [https://perma.cc/HMU7-B49Z]; Jodi Kantor \& Megan Twohey, Harvey Weinstein Paid Off Sexual Harassment Accusers for Decades, N.Y. Times (Oct. 5, 2017), https://www.nytimes.com/2017/10/05/us/harvey-weinstein-harassment-allegations.html [https://perma.cc/E5T7-HSCD].

2. See Farrow, supra note 1; Kantor \& Twohey, supra note 1.

3. Kantor \& Twohey, supra note 1 (relating one woman's advice to a peer that she "wear a parka when summoned for duty [by Weinstein] as a layer of protection against unwelcome advances").

4. See Farrow, supra note 1.

5. See Libby Hill, Seth MacFarlane Reveals Truth About His 2013 Harvey Weinstein Joke, L.A. TIMES (Oct. 11, 2017), https://www.latimes.com/entertainment/la-et-entertainment-news-updates-sethmacfarlane-reveals-truth-about-his-1507755303-htmlstory.html [https://perma.cc/J98J-HPRB] (describing host Seth MacFarlane's quip regarding nominees for best supporting actress: "Congratulations... [y]ou five ladies no longer have to pretend to be attracted to Harvey Weinstein"). MacFarlane's joke received a "considerable response from the room," id., including "relatively raucous laughter." Maya Oppenheim, Seth MacFarlane Made Joke About Harvey Weinstein and Women at 2013 Oscars, INDEPENDENT (Oct. 11, 2017), https://www.independent.co.uk/artsentertainment/films/news/seth-macfarlane-harvey-weinstein-joke-oscars-2013-women-sexual-

harassment-allegations-a7994506.html [https://perma.cc/7WY2-WNGX]. MacFarlane has since explained that he made the joke approximately two years after a female friend and colleague confided in him regarding an inappropriate sexual advance that she received from Weinstein. See id.

6. See Farrow, supra note 1; Kantor \& Twohey, supra note 1.

7. Cf. Maria LaMagna, Why Sexual Harassers Keep Offending, MARKeTWATCH (Dec. 28, 2017), https://www.marketwatch.com/story/one-major-reason-why-sexual-harassers-can-continue-2017-10-21 [https://perma.cc/B5PK-N6BR] (hereinafter "LaMagna I") (“[T]he social media campaign \#metoo suggests hundreds of thousands, or even millions of women have experienced harassment in the workplace.").

8. See id.; Rhitu Chatterjee, A New Survey Finds 81 Percent of Women Have Experienced Sexual Harassment, NPR (Feb. 21, 2018), https:/www.npr.org/sections/thetwo-way/2018/02/21/587671849/anew-survey-finds-eighty-percent-of-women-have-experienced-sexual-harassment [https://perma.cc/R5BJ-2Y55]. 
with millions of people engaging with the \#MeToo movement, further exposing the breadth of this problem across society. ${ }^{9}$

Amidst the outrage and disbelief, however, another reaction has emergeda sort of desperate handwringing, as academics and members of the media and the public brood about what can be done to prevent this type of misconduct from continuing to occur. ${ }^{10}$ Even the Equal Employment Opportunity Commission (EEOC), a purported expert on fostering fair and unbiased workplace relations, has expressed befuddlement regarding this issue. In June 2016, months prior to Harvey Weinstein and \#MeToo occupying the headlines, the EEOC's Select Task Force on the Study of Harassment in the Workplace issued a lengthy report. ${ }^{11}$ In the report, the authors wondered, "[w]ith legal liability long ago established, with reputational harm from harassment well known, with an entire cottage industry of workplace compliance and training adopted and encouraged for 30 years, why does so much harassment ... take place in so many of our workplaces ... [and] what can be done to prevent it?"12

This article presents one possible answer to that question. Using longstanding principles of remedies law, this paper considers whether applying a little known but powerful doctrine known as the faithless servant doctrine to perpetrators of workplace sexual harassment could provide substantial deterrence.

The faithless servant doctrine permits the disgorgement or forfeiture of compensation from individuals who have breached their duty of loyalty. ${ }^{13}$ The doctrine is restitutionary in nature, meaning that it focuses on a wrongdoer's

9. Cassandra Santiago \& Doug Criss, An Activist, a Little Girl and the Heartbreaking Origin of 'MeToo', CNN (Oct. 17, 2017), https://www.cnn.com/2017/10/17/us/me-too-tarana-burke-origintrnd/index.html [https://perma.cc/8QH8-UW92] (citing Facebook's assertion that in less than 24 hours following the announcement of the hashtag, 4.7 million people around the world engaged in the "Me too" conversation, with more than 12 million posts, comments and reactions).

10. See, e.g., Sexual Harassment Training is Largely Ineffective, PSYchol. TODAY (Dec. 13, 2017), https://www.psychologytoday.com/us/blog/evidence-based-living/201712/sexual-harassmenttraining-is-largely-ineffective [https://perma.cc/G3TQ-D4EV]; see also Claire Cain Miller, Sexual Harassment Training Doesn't Work. But Some Things Do, N.Y TIMES (Dec. 11. 2017), https://www.nytimes.com/2017/12/11/upshot/sexual-harassment-workplace-prevention-effective.html [https://perma.cc/J5YE-X9A5]; Roger Showley, Sexual Harassment Training Expanded - But Effectiveness Questioned, SAN DIEGO UnION Tribune (Feb. 12, 2018), https://www.sandiegouniontribune.com/business/growth-development/sd-fi-sextraining-20180212story.html [https://perma.cc/3FLQ-6VU6].

11. Chai R. Feldblum \& Victoria A. Lipnic, EeOC, Select Task Force on the Study of HARASSMENT IN THE WORKPLACE (2016), https://www.eeoc.gov/eeoc/task_force/harassment/report.cfm [https://perma.cc/KE33-QBFJ] (hereinafter "EEOC Task Force Report").

12. Id. at ii. Notably, the EEOC Task Force Report covered a broader range of harassment than is the focus of this paper, including not only sexual harassment, but also harassment on the basis of race, disability, age, ethnicity, color, and religion. See id at iv.

13. Barbara J. Van Arsdale, Annotation, Application of "Faithless Servant Doctrine," 24 A.L.R. 6th 399 (originally published in 2007) (describing faithless servant doctrine as providing that "an agent is entitled to no compensation for conduct which ... is a breach of his or her duty of loyalty"). 
unjust gain rather than on a victim's loss. ${ }^{14}$ While the contours of the faithless servant doctrine can vary significantly from one jurisdiction to the next, ${ }^{15}$ and while even the doctrine's name may differ from jurisdiction to jurisdiction, ${ }^{16}$ the underlying notion of using compensation forfeiture to respond to employees' wrongful conduct remains a theme for courts that apply these restitutionary principles. ${ }^{17}$

Using Harvey Weinstein and his misdeeds as a case study, this article explores the extent to which conventional models for preventing workplace sexual harassment have remained largely ineffective. The article further examines whether a dramatic shift in how businesses and courts approach this problem - a shift like that which would be embodied by the faithless servant doctrine and other compensation forfeiture tools - could create the significant cultural change necessary to decrease this misbehavior. This article largely represents a thought experiment-a wondering about how society, seemingly mired in rehashing the same, marginally effective "solutions" to the problem of sexual harassment at work, might perhaps begin to think about harassment prevention in another way. While by no means a perfect fit for Weinstein's situation, and while perhaps a stretch of restitutionary doctrine more generally, this paper is intended to provide a fundamentally different way of thinking about this longstanding problem within the workplace.

Part I of this article provides a brief overview of the Weinstein scandal as an example of the sexual misconduct that has plagued many modern workplaces. Part II explains why existing means of addressing sexual harassment have proven ineffective, and argues that changes in the broader workplace culture are required to reduce instances of this misconduct at work. Part III, finally, explains why the faithless servant doctrine and similar compensation forfeiture mechanisms could in some contexts create the type of cultural shift necessary to decrease sexual harassment at work. ${ }^{18}$ Part III further explores the complications in applying

14. See Dan B. DobBs, LAW Of Remedies § 4.1(1) (2d ed., West Pub. Co. 1993) (describing restitution as "a return or restoration of what the defendant gained in a transaction").

15. See infra $\S$ III.B.2 and accompanying text.

16. See infra note 148 and accompanying text.

17. While the technical definitions of "compensation forfeiture" and "compensation disgorgement" may differ somewhat, see, e.g., Forfeiture, BLACK's LAW DiCTIONARY (Bryan A. Garner, ed. 11th ed. 2019) (defining "forfeiture" as, inter alia, "[t]he divestiture of property without compensation" or as " $[\mathrm{t}] \mathrm{he}$ loss of a right, privilege, or property because of a crime, breach of obligation, or neglect of duty. . ."); $c f$. $i d$. (defining "disgorgement" as "[t]he act of giving something up (such as profits illegally obtained) on demand or by legal compulsion"), this paper uses these terms interchangeably, generally referring to situations where a court mandates that a high level employee return the compensation that he/she received during a period in which that individual also engaged in misconduct related to their job.

18. This paper refers to "sexual misconduct," "sexual misbehavior," and "sexual harassment," often using these terms (and other similar terms) somewhat interchangeably. While much of the conduct described in this paper would rise to the level of legally actionable sexual harassment, see Burlington Indus. v. Ellerth, 524 U.S. 742, 752 (1998) (defining quid pro quo and hostile environment sexual harassment), and/or criminally actionable sexual assault, see, e.g., CA Penal Code $\S 243.4$, even sexual misconduct that does not trigger civil or criminal liability can create an undesirable working environment for those targeted by such behavior. While this paper lumps much of this behavior together, it by no means 
these forfeiture ideas to situations like that involving Harvey Weinstein, where the harasser's employer (here, the Weinstein Company) may have recklessly ignored or even been complicit in the underlying wrongful conduct.

\section{HARVEY WeInSTEIn AS A CASE STUdy FOR SEXUAL HARASSMENT GONE UNCHECKED}

For many years, Harvey Weinstein's name seemed synonymous with movie gold. As the co-founder of the production and distribution companies Miramax and the Weinstein Company, ${ }^{19}$ Weinstein helped to create such movie masterpieces and cult classics as "Pulp Fiction," "The English Patient," "The Crying Game," and countless others. ${ }^{20}$ The Weinstein Company's films have grossed an estimated \$1.3 billion worldwide, ${ }^{21}$ garnering 303 Oscar nominations and 75 Academy Awards. ${ }^{22}$ Prior to the scandal breaking, in 2016, Weinstein told the Hollywood Reporter that his studio was worth between $\$ 700$ million and $\$ 800$ million, "in a worst case scenario."23 Also prior to his public downfall, Weinstein's personal wealth was estimated to fall somewhere between $\$ 240$ million and $\$ 300$ million. ${ }^{24}$ Weinstein achieved such financial success all while being well known within Hollywood for his explosive temper and mercurial nature, ${ }^{25}$ and was able to amass tremendous power within the industry - whether in spite of or because of his volatile temperament. ${ }^{26}$ Indeed, Weinstein's sway within the entertainment industry before his fall was virtually undisputed. As one reporter observed, "at the annual awards ceremonies, [Weinstein] has been thanked more than almost anyone else in movie history, ranking just after Steven Spielberg and right before God." ${ }^{27}$

suggests a "one size fits all" solution for this broad range of objectionable conduct. Rather, this paper posits that the Faithless Servant Doctrine and similar disgorgement strategies could be applied to a broad range of sexual misbehavior to deter this type of workplace conduct, while still recognizing that different degrees of misconduct might warrant slightly different responses. Cf. EEOC Task Force Report, supra note 11, at iv (noting that the Report's authors "did not confine ourselves to the legal definition of workplace harassment, but rather included examination of conduct and behaviors which might not be 'legally actionable,' but left unchecked, may set the stage for unlawful harassment”); see also id. at 3.

19. See Farrow, supra note 1.

20. See id.

21. See Natalie Robehmed, Why the Weinsteins Aren't Among Hollywood's Richest Power Brokers, FORBES (Aug. 19, 2015), https://www.forbes.com/sites/natalierobehmed/2015/08/19/why-the-weinsteinsarent-among-hollywoods-richest-power-brokers/\#6d8c1101a3f7 [https://perma.cc/YS8L-ALWL].

22. See id.; Farrow, supra note 1.

23. Gregg Kilday, Harvey Weinstein Explains Recent Movie Release Shifts, TV Growth and Oscar Prospects $(Q \& A)$, HOLlywOOD REPORTER (July 21, 2016), https://www.hollywoodreporter.com/news/harvey-weinstein-explains-movie-release-913142 [https://perma.cc/8AUN-MGAD].

24. Brad Tuttle, Harvey Weinstein is One of the Richest Men in Hollywood. Here's What We Know About his Money, MONEY (Oct. 12, 2017), http://money.com/money/4978630/harvey-weinstein-networth-money/ [https://perma.cc/EB6C-ZX7K].

25. See Farrow, supra note 1.

26. See id.

27. Id. 
It is within the context of such tremendous power that Weinstein faced an onslaught of harassment allegations in fall of $2017 .{ }^{28}$ Perhaps equally shocking are the scope, scale, and extreme nature of the allegations against Harvey Weinstein. As has now become common knowledge, Weinstein has been accused of sexual misconduct by more than 100 women, ${ }^{29}$ with allegations that span back for more than three decades, during Weinstein's time heading the Weinstein Company as well as during his previous tenure at the helm of Miramax. ${ }^{30}$ His alleged victims include some of the most prominent names in the entertainment industry, from Gwyneth Paltrow to Rosanna Arquette to Angelina Jolie, as well as scores of other lesser-known actresses. ${ }^{31}$ Weinstein often would begin by attempting to lure women into private rooms, requesting a massage or asking them to watch him bathe, but the allegations against him also include multiple counts of forced sexual contact, claims that Weinstein exposed himself or masturbated in front of unwilling women, as well as at least four allegations of sexual assault or rape. ${ }^{32}$ According to some accounts, female Weinstein employees were "used as 'honeypots' to lure victims into meetings under the pretense of normal business, ${ }^{, 33}$ only for Weinstein to later dismiss them, leaving him alone with his intended targets. ${ }^{34}$ Moreover, as a buffer against the exposure of his misdeeds, Weinstein mandated that all employees adhere to a strict code of silence, under which employees were prohibited from criticizing the Weinstein Company or its leaders in any way that could harm the company's or its leaders' reputations. ${ }^{35}$

28. See id.

29. See Amelia Schonbeck, The Complete List of Allegations Against Harvey Weinstein, THE CuT (Jan. 6, 2020), https://www.thecut.com/2020/01/harvey-weinstein-complete-list-allegations.html [https://perma.cc/B9XY-8LT9]; Sara M. Moniuszko \& Cara Kelly, Harvey Weinstein Scandal: A Complete List of the 87 Accusers, USA TODAY (Oct. 27, 2017), https://www.usatoday.com/story/life/people/2017/10/27/weinstein-scandal-complete-listaccusers/804663001/ [https://perma.cc/G7MT-6LFU].

30. See Kanyakrit Vongkiatkajorn, Harvey Weinstein Made an Absolute Fortune Off Movies Featuring his Alleged Victims, MOTHER JONES (Oct. 11, 2017), https://www.motherjones.com/media/2017/10/harvey-weinstein-made-an-absolute-fortune-off-moviesfeaturing-his-alleged-victims/ [https://perma.cc/A4WG-BF8H].

31. See id.

32. See id.; Farrow, supra note 1; Daniel Hemel \& Dorothy S. Lund, It May Not Matter What the Weinstein Kompany Kew, AtlantiC (Oct. 14, 2017), https://www.theatlantic.com/business/archive/2017/10/harvey-weinstein-company-legalconsequences/542838/ [https://perma.cc/4SGC-G2E8] (hereinafter "Hemel \& Lund I").

33. Ryan Faughnder, Victoria Kim \& Stephen Battaglio, As Harvey Weinstein Sex Scandal Grows, One Accuser Says His Company was Negligent, L.A. Times (Oct. 25, 2017), https://www.latimes.com/local/lanow/la-fi-ct-harvey-weinstein-huett-20171025-story.html [https://perma.cc/C36R-L927].

34. Id.

35. Kantor \& Twohey, supra note 1. 
In addition to the individual consequences Weinstein faces-including both criminal charges ${ }^{36}$ and civil lawsuits, ${ }^{37}$ - the Weinstein Company and its Board of Directors may also be liable for their alleged complicity in Weinstein's schemes. Indeed, as discussed in greater detail below, the Weinstein Company's Board of Directors at best seemed to turn a blind eye to Weinstein's misconduct, adopting an almost willful refusal to acknowledge behavior that was common knowledge across the majority of the entertainment industry. ${ }^{38}$ At worst, the Weinstein Company was actively cooperating with the harassment: The Weinstein Company repeatedly declined to investigate Weinstein in the face of harassment allegations, while quietly settling claims with women who accused Weinstein of misconduct, and while continuing to renew Weinstein's lucrative employment contract. ${ }^{39}$ This failure to investigate and subsequent cover-up demonstrates an apparent willingness to give Weinstein broad discretion to abuse scores of women over three decades so long as the Oscars and profits continued to pile up. Such apparent complicity led at least one alleged target of Weinstein's misconduct, actress Dominique Huett, to file a negligence suit against the Weinstein Company, claiming that the company knew about Weinstein's alleged misconduct and failed to protect the women with whom Weinstein came into contact. ${ }^{40}$ Weinstein, Miramax, and the Weinstein Company also previously

36. See Jessica M. Goldstein, From Racketeering Claims to Rape Charges, a Guide to All the Cases Against Harvey Weinstein, THINKPROGESS.ORG (Oct. 25, 2018), https://thinkprogress.org/the-manymany-cases-against-harvey-weinstein-a-complete-guide-d14a1d99a0cd/ [https://perma.cc/229U-LXS4]; Eric Levenson \& Elizabeth Joseph, Harvey Weinstein Judge Declines to Dismiss Charges in Rape Case, Sets Pretrial Hearing for March, CNN (Dec. 20, 2018), https://www.cnn.com/2018/12/20/us/harveyweinstein-court-charges/index.html [https://perma.cc/R8X3-KT7D] (reporting Weinstein faced at least five felony charges, including predatory sexual assault and rape, in connection with two women in two unrelated incidents); Jan Ransom and Jose A. Del Real, Harvey Weinstein Charged with Rape in Los Angeles as N.Y. Trial Starts, N.Y. TIMES (Jan. 10, 2020), https://www.nytimes.com/2020/01/06/nyregion/harvey-weinstein-trial.html [https://perma.cc/2L4AH7MQ] (reporting that prosecutors in Los Angeles filed additional rape charges against Weinstein based on allegations involving two other women). In February of 2020, a New York jury found Weinstein guilty of first-degree criminal sexual act and third degree rape. Jan Ransom, Harvey Weinstein's Stunning Downfall: 23 Years in Prison, N.Y. Times (Published Mar.11, 2020, Updated Mar. 12, 2020), https://www.nytimes.com/2020/03/11/nyregion/harvey-weinstein-sentencing.html [https://perma.cc/2C7Q-H8NS]. Weinstein was sentenced to 23 years in prison. Id.

37. Weinstein also faces multiple civil suits, either individually or as part of other litigation against his former company, see Goldstein, supra note 36; Dominic Patten, Harvey Weinstein Fails to Get Class Action Tossed; Bob Weinstein, Disney, TWC Board \& David Glasser Dropped From Case, DEADLINE (Apr. 18, 2019), https://deadline.com/2019/04/harvey-weinstein-sexual-assault-lawsuit-class-actiondismissal-failure-bob-weinstein-twc-1202598535/ [https://perma.cc/33GW-8GGN] (reporting civil suits against Weinstein in both the United States and the United Kingdom); Associated Press, Judge Allows Sex-Trafficking Claim in Suit Against Harvey Weinstein, HOllywood RePORTER (Apr. 18, 2019), https://www.hollywoodreporter.com/news/judge-allows-sex-trafficking-claim-suit-harvey-weinstein1203150 [https://perma.cc/99XV-QSPU]; Tom Connick, Harvey Weinstein Facing UK Civil Claim Over Sexual Assault Allegations, NEW MusicAl EXPRESS (Nov. 27, 2017), https://www.nme.com/news/film/harvey-weinstein-facing-uk-civil-claim-sexual-assault-allegations2165809 [https://perma.cc/AR35-82BB].

38. See infra § III.D and accompanying text.

39. See id.

40. See Faughnder et al., supra note 33. 
faced class action charges under the Racketeer Influenced and Corrupt Organizations (RICO) Act, among other claims, ${ }^{41}$ but those claims were dismissed as to the Weinstein Company (although not as to Harvey Weinstein himself) in April 2019. ${ }^{42}$

Beyond any legal consequences, the financial toll on Weinstein and his former company is estimated at $\$ 390$ to $\$ 490$ million. While it is difficult to determine with certainty the company's value prior to the scandal, previouslynoted estimates range from $\$ 700$ million to $\$ 800$ million. In the wake of the scandal, the Weinstein Company tried and failed to broker a deal with an investor group to purchase the company for $\$ 500$ million. ${ }^{43}$ That deal collapsed after New York Attorney General Eric Schneiderman filed a civil rights lawsuit against the company. ${ }^{44}$ Ultimately, the Weinstein Company filed for Chapter 11 bankruptcy protection in March $2018,{ }^{45}$ and a private equity firm acquired the company's assets for \$289 million in July $2018 .{ }^{46}$

The impact of the scandal on Weinstein's personal fortune is more difficult to determine, but likely is less consequential. On the one hand, at the time the scandal broke, Weinstein held a more than $20 \%$ stake in the (soon-to-be defunct) Weinstein Company. ${ }^{47}$ As a major equity holder in the company, Weinstein's equity was "expected to be wiped out" by the company's bankruptcy proceedings. ${ }^{48}$ Moreover, Weinstein's wife, Georgina Chapman, announced that she was leaving Weinstein in the wake of the scandal, ${ }^{49}$ and this divorce may prove financially costly to him as well. Yet despite these financial hits, Weinstein's personal financial future seems far from bleak: Weinstein likely

41. See The Weinstein Company and Others Face RICO Claim in Wake of Sexual Assault 'Cover Ups,' FORBES (Dec. 6, 2017), https://www.forbes.com/sites/legalentertainment/2017/12/06/theweinstein-company-and-others-face-rico-claim-in-wake-of-sexual-assault-cover-ups/\#7ed55f1 d48fe [https://perma.cc/KQS3-LXP6]

42. See Patten, supra note 37; Associated Press, supra note 37.

43. See Anna Menta, What is The Weinstein Company Worth? Studio Declares Bankruptcy After $\$ 500$ Million Deal Collapses, NewsweEK (Feb. 26, 2018, 1:51 PM), https://www.newsweek.com/weinstein-company-net-worth-declares-bankruptcy-820270

[https://perma.cc/4L3M-5ZY8]; Chris Isidore, Remains of the Weinstein Company Sold - to the Only Real Bidder, CNN BuSINESS (May 2, 2018, 11:32 AM), https://money.cnn.com/2018/05/02/media/weinsteincompany-bidder/index.html [https://perma.cc/9Y8Q-U8DB].

44. See Elahe Izadi, The Weinstein Co. Declares Bankruptcy. Here's What That Means and What Could Be Next, WASH. POST (Mar. 20, 2018, 10:03 AM), https://www.washingtonpost.com/news/artsand-entertainment/wp/2018/03/20/the-weinstein-company-declares-bankruptcy-heres-what-that-meansand-what-could-be-next/?utm_term=.3b7e456916b5 [https://perma.cc/8AZF-6TVZ]; Menta, supra note 43.

45. Izadi, supra note 44; see Menta, supra note 43.

46. Dawn C. Chmielewski, Lantern Entertainment Closes \$289 Million Acquisition of the Weinstein Co's Assets, DEADLINE (July 18, 2018), https://deadline.com/2018/07/lantern-entertainmentcloses-289-million-acquisition-weinstein-co-s-assets-1202427141/ [https://perma.cc/W7U8-QQD6]

47. See Josh Dickey, Want to be Sure You're Not Paying Harvey Weinstein? There's Only One Way, MASHABLE (Oct. 19, 2017), https://mashable.com/2017/10/19/harvey-weinstein-make-moneymovies-films-dimension-co [https://perma.cc/9Y8Q-U8DB].

48. See Izadi, supra note 44

49. See Tuttle, supra note 24; Oppenheim, supra note 5. 
participated in hundreds of backend revenue deals related to his films ${ }^{50}$ many of which are classic movies that not only earned money at the time of their release, but which have continued (and presumably will continue) to line Weinstein's pockets every time they are enjoyed.$^{51}$ Moreover, reports indicate that Weinstein reached a tentative settlement of the civil claims against him for $\$ 47$ million, all of which apparently would be paid by the Weinstein Company's insurance providers. ${ }^{52}$ While some accusers have elected not to join this settlement, and while criminal prosecutions against Weinstein remain ongoing despite this settlement, this resolution renders it quite possible that Weinstein can walk away from his wrongdoing with minimal direct personal financial impact. ${ }^{53}$

\section{MINIMIZING HARASSMENT IN THE WORKPLACE AND BEYOND}

While much about the Weinstein scandal might seem shocking and unique, Weinstein's conduct resembles the type of behavior that takes place in a variety of workplaces. The EEOC received 7,609 charges of sexual harassment in fiscal year 2018 alone, ${ }^{54}$ representing almost $10 \%$ of the 76,418 total charges filed with the agency that year. ${ }^{55}$ According to the EEOC, anywhere between $25 \%$ and $85 \%$ of women report experiencing sexual harassment at work, and this statistic does not include the many instances of sexual harassment which go unreported and even unidentified by the women targeted. ${ }^{56}$ The fact that in this case, such

50. See Dickey, supra note 47.

51. See Kelsea Stahler, Should We Watch the Hundreds of Films Produced by Harvey Weinstein? Female Film Critics Weigh In, BusTLE (Oct. 12, 2017), https:/www.bustle.com/p/should-we-watch-thehundreds-of-films-produced-by-harvey-weinstein-female-film-critics-weigh-in-2894326

[https://perma.cc/4RVP-DH6V] (observing that “ignoring Weinstein's impact on the landscape of film is impossible" and noting that he "executive produced over 100 films, so many of which are considered classics"); Dickey, supra note 47 (asserting that the only certain way to avoid putting money in Weinstein's pocket is to stop watching his movies).

52. See Megan Twohey and Jodi Kantor, Weinstein and His Accusers Reach Tentative \$25 Million Deal, N.Y. Times (Published Dec. 11, 2019, Updated Jan. 22, 2019), https://www.nytimes.com/2019/12/11/us/harvey-weinstein-settlement.html [https://perma.cc/K5TASRPK] (noting that $\$ 25$ million of the tentative settlement is set to go directly to Weinstein's accusers). Further, \$12 million in legal fees for the company's officers and directors (including Weinstein) is included in this tentative settlement. See id.

53. See Lucy Osborne, Harvey Weinstein: fourth accuser opts out of settlement to pursue own claim, GUARDIAN (Jan. 19, 2020) https:/www.theguardian.com/film/2020/jan/19/harvey-weinsteinaccuser-settlement [https://perma.cc/7GBF-5E6N]; Ransom and Del Real, supra note 36; see also Ransom, supra note 36 (noting Weinstein's convictions and sentencing with respect to criminal charges in New York).

54. U.S. Equal Emp. Opportunity COMm'n, Charges Alleging SEX-Based Harassment $\begin{array}{llllllll}\text { (CHARGES FILED } & \text { WITH } & \text { EEOC) } & \text { FY } & 2010 & \text { FY } & \text { 2019, }\end{array}$ https:/www.eeoc.gov/eeoc/statistics/enforcement/sexual_harassment_new.cfm [https://perma.cc/T7XG$\mathrm{U} 247]$.

55. See U.S. Equal Emp. Opportunity Comm'n, Charge Statistics (Charges Filed With EEOC) FY 1997 THROUGH FY 2019, https://www.eeoc.gov/eeoc/statistics/enforcement/charges.cfm [https://perma.cc/CY73-TTC4].

56. See EEOC Task Force Report, supra note 11, at 8; Nilofer Merchant, The Insidious Economic Impact of Sexual Harassment, HARV. BUS. REV. (Nov. 29, 2017), https://hbr.org/2017/11/the-insidiouseconomic-impact-of-sexual-harassment [https://perma.cc/6D83-2L2N]; $c f$. Chatterjee, supra note 8 
misbehavior originated from a famous movie executive-as opposed to an employee in a less glamorous workplace-renders the harassment perhaps different in degree but certainly not in kind. As one of Weinstein's own victims observed, Weinstein's behavior constituted "[t]extbook sexual harassment," encompassing the same sort of unchecked power dynamics that could exist in a variety of settings. ${ }^{58}$ Therefore, there may be lessons to draw from Weinstein's downfall that could inform approaches to minimizing workplace sexual harassment more generally.

In the weeks and months following the Weinstein scandal breakingparticularly as additional accounts of workplace harassment began to emerge across various other industries - governmental officials, industry insiders, and members of the public wondered how such appalling and disgraceful behavior could have gone on unabated for so long in so many industries. ${ }^{59}$ More affirmatively, many of these same individuals began the search for solutions to this problem-began trying to examine ways in which inappropriate sexual misconduct at work might be minimized or eliminated altogether. The vast majority of businesses already seemed to have undertaken steps that, at first glance, one reasonably might conclude would prevent this behavior. For example, in a survey of human resources professionals conducted in the fall of 2017, approximately $90 \%$ of the respondents said that their companies had a policy against sexual harassment. ${ }^{60}$ In the same survey, approximately $71 \%$ of respondents said that their companies conduct some form of sexual harassment training. ${ }^{61}$

Despite these commitments to policies and training, however, sexual harassment claims continue to deluge the EEOC, comprising a substantial portion of the complaints that the agency receives every year. ${ }^{62}$ Such statistics naturally beg the question of the effectiveness of current practices. If companies have been adhering to these policies and practicing this training, how could \#MeToo and similar movements have exposed such far-reaching incidents of harassment in such a wide variety of workplaces? Apparently, policies against workplace harassment are not enough; training alone will not abate this problem.

(citing survey finding that $81 \%$ of women have experienced sexual harassment at work); Stahler, supra note 51 (positing that at least one third of all women experience sexual harassment at work).

57. Farrow, supra note 1.

58. See id. (quoting Weinstein victim's analogy that "[i]t's a pretty clear case of sexual harassment when your superior, the C.E.O., asks one of their inferiors, a temp, to have sex with them, essentially in exchange for mentorship").

59. See, e.g., Farrow, supra note 1; Kantor \& Twohey, supra note 1; Faughnder et al., supra note 33; Jessica Valenti, It's No Accident That Sexual Harassers Rise Up the Ranks, GUARDIAN (Nov. 4, 2017, 6:00 AM), https://www.theguardian.com/commentisfree/2017/nov/04/sexual-harassers-rise-ranks-redflag [https://perma.cc/8XQF-7PAT].

60. See Maya Rhodan, Does Sexual Harassment Training Work? Here's What the Research Shows, TIME (Nov. 21, 2017), http://time.com/5032074/does-sexual-harassment-training-work-heres-what-theresearch-shows/ [https://perma.cc/P62A-KZNB]; EEOC Task Force Report, supra note 11.

61. See Rhodan, supra note 60.

62. See supra notes 55-56 and accompanying text. 
Rather, research indicates that other steps must be taken to deter workers from engaging in - and companies from tolerating - this type of inappropriate workplace behavior. ${ }^{63}$

\section{A. The Inadequacy of Traditional Mechanisms for Countering Harassment at Work}

Despite the increased attention that has been paid to sexual harassment in the workplace, much of the effort that companies have made in attempting to counter this conduct is ineffective and aimed at limiting their own liability. For example, while sexual harassment training has become standard practice in the majority of workplaces, ${ }^{64}$ a wealth of research suggests the inadequacy and ineffectiveness of this training. ${ }^{65}$ For one thing, many employees fail to take such training seriously and are simply "clicking through a PowerPoint, checking a box that you read the employee handbook or attending a mandatory seminar at which someone lectures about harassment while attendees glance at their phones." ${ }^{\prime 66}$ Compounding this problem, the financial and logistical costs associated with inperson training programs mean that many companies now rely upon online tutorials, thereby making it even more difficult to ensure that employees undertake such training thoughtfully and seriously. ${ }^{67}$ Even more concerning, for many companies that implement these programs, reducing workplace harassment may not be the only (or even the primary) goal: The focus, instead, is on corporate self-protection — on "reduc[ing] the likelihood of being named in harassment suits or . . . check[ing] a box for E.E.O.C. purposes." ${ }^{96}$

63. See infra § II.B.

64. See Jena McGregor, Why Sexual Harassment Training Doesn't Stop Harassment, WASH. PosT (Nov. 17, 2017, 11:07 AM), https://www.washingtonpost.com/news/on-leadership/wp/2017/11/17/whysexual-harassment-training-doesnt-stop-harassment/?utm_term=.5c80671 c60a1 [https://perma.cc/KR32$86 \mathrm{KN}]$.

65. See, e.g., Frank Dobbin \& Alexandra Kalev, Training Programs and Reporting Systems Won't End Sexual Harassment. Promoting Women Will, HARv. Bus. Rev. (Nov. 15, 2017), https://hbr.org/2017/11/training-programs-and-reporting-systems-wont-end-sexual-harassment-

promoting-more-women-will [https://perma.cc/6KYK-2F53] (describing mixed results with respect to the effectiveness of sexual harassment training); see generally Rhodan, supra note 60; Mariel Tishma, How Effective is Mandatory Harassment Training?, CHIEF LEARNING OFFICER (Apr. 27, 2018), https://www.chieflearningofficer.com/2018/04/27/effective-mandatory-harassment-training/ [https://perma.cc/T549-4W4H].

66. See Miller, supra note 10; $c f$. McGregor, supra note 64 (describing the "disdain" expressed toward sexual harassment training programs, even by the very individuals who promote such programs).

67. See McGregor, supra note 64.

68. See Miller, supra note 10 (quoting a psychologist at Rice University). Sexual harassment training can bolster an employer's defense against certain types of sexual harassment claims. Under Faragher v. City of Boca Raton, 524 U.S. 775 (1998) and Burlington Indus., Inc. v. Ellerth, 524 U.S. 742 (1998), an employer may have an affirmative defense against claims of harassment that do not involve an adverse employment action if the employer can demonstrate: (1) it took reasonable steps to prevent and promptly correct sexual harassment in the workplace; and (2) the aggrieved employee unreasonably failed to take advantage of the employer's preventive or corrective measures. See Miller, supra note 10; PSYCHOL. TODAY, supra note 10. 
Even when taken seriously by employers and employees, workplace sexual harassment training exhibits severe limitations in its usefulness. Studies indicate that such training does not appear to be effective either at reducing the number of incidents of harassment in the workplace or at shifting the workplace culture toward one that views harassment as a serious problem. ${ }^{69}$ More specifically, while this training generally is credited with increasing employees' knowledge about sexual harassment - for example, teaching workers about the definition of harassment and how to report alleged violations in the workplace ${ }^{70}$-this increased knowledge does not translate into behavioral changes among those inclined to engage in harassment. ${ }^{71}$ In fact, according to at least some research, harassment training actually can reinforce some gender stereotypes, at least in the short term, and can make participants uncomfortable, prompting defensive jokes. ${ }^{72}$ Such findings have led one set of researchers to assert that men who already appeared prone toward engaging in sexual harassment "come out of training with significantly worse attitudes toward harassment, thinking it is no big deal." ${ }^{\text {,3 }}$

\section{B. The Magic Bullet: Changing the Workplace Culture}

If policies and training do not seem to be adequately decreasing the incidence of sexual harassment at work, what other steps might employers take to accomplish this goal? Tellingly, research has revealed that changing the culture within a workplace can reduce the amount of harassment at work. ${ }^{74}$ Research in this area suggests that " $[t]$ o actually prevent harassment, companies need to create a culture in which women are treated as equals and employees treat one another with respect." 75 The EEOC has echoed this finding, asserting that "[w]orkplace culture has the greatest impact on allowing harassment to flourish, or conversely, in preventing harassment."

A workplace's culture encompasses the "patterns of accepted behavior" at work, and "the beliefs and values that promote and reinforce [these patterns of

69. See McGregor, supra note 64; EEOC Task Force Report, supra note 11, at 47.

70. See PSYCHOL. TODAY supra note 10; Miller, supra note 10; EEOC Task Force Report, supra note 11 , at 48 .

71. See Miller, supra note 10; cf. EEOC Task Force Report, supra note 11, at 47 (concluding it is "less probable that training programs, on their own, will have a significant impact on changing employees' attitudes, and they may sometimes have the opposite effect").

72. Miller, supra note 10.

73. Dobbin \& Kalev, supra note 65.

74. See, e.g. Miller, supra note 10; Rhodan, supra note 60; Erika Andersen, 3 Things You Can Do to Change People's Behavior, Forbes (Aug. 17, 2012), https://www.forbes.com/sites/erikaandersen/2012/08/17/3-things-you-can-do-to-change-peoplesbehavior/\#3738d6f57a0a [https://perma.cc/KY9P-5MWU]; see also Merchant, supra note 56 (arguing that "[i]nstead of thinking of sexually predatory behavior as a few (or many) bad seeds, we ask, instead ... how do we change our organizations to rebalance power").

75. Miller, supra note 10.

76. See EEOC Task Force Report, supra note 11, at v; see also id. at 31. 
behavior]." 77 One can think of the "patterns of behavior" within an organization as those things that are deemed acceptable in that workplace - things that are "OK to do." 78 Changing these mechanisms - both patterns of behavior and the individual beliefs that underlie such behavior-is no easy task. To the contrary, seeking such change means undoing opinions, principles, activities and programs that may have come to infuse the very fabric of the workplace. In the sexual harassment context, this means that organizations must not simply go through the motions, but rather must "create a culture in which women are treated as equals and employees treat one another with respect." 79 It means moving from a workplace culture where behavior like Weinstein's has been tolerated and enabled to one where such behavior is not simply no longer the norm, but rather will shock the conscience of those observing such conduct.

While shifting a workplace's culture may be difficult, a wealth of research supports the effectiveness of such efforts in combating harassment. For example, one study found that organizational climate-defined as the "organizational characteristics that communicate tolerance of sexual harassment"-plays a significant role in facilitating sexual harassment in the workplace.$^{80}$ Specifically, researchers found that female employees who believe that their organization tolerates sexual harassment (demonstrated by complaints not being taken seriously, by the presence of risks associated with complaining, and by the unlikelihood of perpetrators being punished) end up experiencing higher levels of harassment at work. ${ }^{81}$ This undoubtedly would dovetail with the experiences of employees at the Weinstein Company: Surely, an employee of the Weinstein Company, observing the company's Board of Directors renew Weinstein's contract in the face of multiple allegations of harassment ${ }^{82}$-allegations that had become common knowledge among employees and others ${ }^{83}$ - would not believe that he/she was working within a workplace culture that truly took seriously such inappropriate conduct. Potential victims therefore might stay silent out of fear of not being taken seriously, and other potential perpetrators might feel empowered to mirror Weinstein's conduct. In other words, such employees might not simply feel disgruntled about the way in which the Weinstein Company handled concerns about harassment; according to this research, such employees would be more likely themselves ultimately to experience sexual harassment at work.

So how could companies like the Weinstein Company truly "change the culture" within the workplace to emphasize that harassment will not be tolerated? While no single formula will work within every organization, research supports

77. Andersen, supra note 74.

78. See id.

79. Miller, supra note 10.

80. Louise F. Fitzgerald et al., Antecedents and Consequences of Sexual Harassment in Organizations: A Test of an Integrated Model, 82 J. OF APPLIED Psychol., No. 4, 578, 579 (1997) (citations omitted).

81. Id. at 586 .

82. See Faughnder et al., supra note 33; Hemel \& Lund I, supra note 32.

83. See supra notes $2-6$ and accompanying text. 
several key themes that seem effective in triggering workplace cultural change: Organizations must foster a workplace culture that exhibits a serious and sober approach to sexual harassment; they must respond to incidents of harassment with swift and severe ramifications; and they must foster an overall power structure that inhibits those in power from taking advantage of others who fall lower in the hierarchy. ${ }^{84}$

\section{Changing the Workplace Culture by Modeling a Serious, Sober Approach to Workplace Sexual Harassment}

One way in which employers might alter their workplace culture to decrease the incidence of sexual harassment more forcefully is to model the seriousness with which they condemn such misbehavior. As one author who studies cultural change has pointed out, "normalization" forms an important part of creating cultural change. ${ }^{85}$ Before individuals will change the way that they behave, "[they] need to feel that "people like me act this way, and people I admire and want to emulate act this way." 86 Generating change requires "giv[ing] [employees] some evidence that their peers (at least the ones they like) and their role models are behaving in those ways." ${ }^{~} 77$ Thus, employers must convey to their workforce that inappropriate sexual misconduct at work will not be countenanced or accepted - that such misconduct falls outside the bounds of permissible workplace behavior.

Part of normalizing a culture that refuses to countenance harassment (or, perhaps, de-normalizing a culture in which harassment is accepted) involves destroying any notion that a workplace harasser can "get away with" such behavior and eliminating any impunity that the harasser otherwise might feel. One renowned researcher in this area concurs that "[i]mpunity plays a large

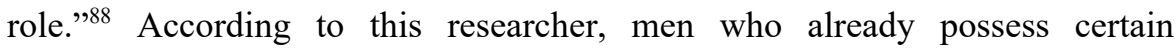
characteristics will engage in sexually harassing behavior when they are put in situations where the system suggests that they can do so while avoiding punishment. ${ }^{89}$ The EEOC Task Force more straightforwardly observed that "[o]rganizational cultures that tolerate harassment have more of it, and workplaces that are not tolerant of harassment have less of it." ${ }^{\text {90 }}$ Organizations

84. See infra §§ II.B.1-3.

85. See Andersen, supra note 74.

86. Id. (italics omitted).

87. $I d$.

88. William Wan, What Makes Some Men Sexual Harassers? Science Tries to Explain the Creeps of the World, WASH. POST (Dec. 22, 2017), https://www.washingtonpost.com/news/speaking-ofscience/wp/2017/12/20/what-makes-some-men-sexual-harassers-science-tries-to-explain-the-harveyweinsteins-of-the-world/?utm_term=.1440477d5746 [https://perma.cc/H2M5-XQQX] (quoting John Pryor, a psychologist at Illinois State University).

89. See id. (quoting Pryor, a psychologist).

90. EEOC Task Force Report, supra note 11, at 32; see also id. at 31 (noting that one key factor for reducing harassment at work is "leadership and commitment to a diverse, inclusive, and respectful workforce in which harassment is simply not acceptable ..."). 
therefore must model, from the top down, the seriousness with which they approach concerns about harassment, from having top executives repeatedly vocalize their condemnation of such behavior, ${ }^{91}$ to having leaders attend and/or endorse any harassment training. ${ }^{92}$

Applying these ideas to the Weinstein scandal makes clear the extent to which the Weinstein Company modeled the exact opposite environment that would be required to minimize harassment in the workplace. The notion of Weinstein or any of his key executives modeling a zero tolerance attitude towards sexual harassment should be laughable to anyone who knows about Weinstein's misdeeds and the extensive cover-up that his staff engineered. ${ }^{93}$ Countless witnesses have come forward in the wake of the scandal attesting to the perceived invincibility of Weinstein within the organization - the extent to which Weinstein operated seemingly unaccountable to anyone within the company. ${ }^{94}$ As one victim observed about Weinstein's behavior, "I know that everybody - I mean everybody - in Hollywood knows that it's happening .... He's not even really hiding.... [T] he way he does it, so many people are involved and see what's happening. But everyone's too scared to say anything." 95 Even those who attempted to turn to the Weinstein Company's human resources department to address their concerns found themselves faced with an entity that refused to act: According to one insider, such victims purportedly were told, "This is his company. If you don't like it, you can leave."96

Organizations can model a serious and sober approach to sexual harassment not only by putting in place effective policies and procedures that oppose harassment ${ }^{97}$ (something that most organizations have been doing with minimal effect for decades) ${ }^{98}$ but also by backing up those policies and procedures with resources in the form of money and time. ${ }^{99}$ Specifically, research indicates that the most effective sexual harassment training lasts at least 4 hours and takes place in person, tailored to the particular workplace. ${ }^{100}$ Such robust training won't come cheap. Yet by demonstrating the seriousness with which the employer

91. See Dobbin \& Kalev, supra note 65 (advising that "CEOs must take a strong public stand against workplace harassment—and keep repeating that message").

92. See Rhodan, supra note 60.

93. Cf. Farrow, supra note 1 (explaining that many current and former executives and assistants at the Weinstein Company knew of the allegations and helped cover up for Weinstein).

94. See Kantor \& Twohey, supra note 1 (discussing many victims' fear of retaliation by Weinstein if they reported his misconduct and observing that "[s]peaking up could have been costly"); Farrow, supra note 1 (echoing victims' concerns regarding retaliation by Weinstein).

95. Farrow, supra note 1; Kantor \& Twohey, supra note 1 (quoting victim Ashley Judd's remark that " $[\mathrm{w}]$ omen have been talking about Harvey amongst ourselves for a long time, and it's simply beyond time to have the conversation publicly").

96. See Farrow, supra note 1.

97. See EEOC Task Force Report, supra note 11, at 33.

98. See supra § II.A.

99. See EEOC Task Force Report, supra note 11, at 33.

100. See Miller, supra note 10 (citations omitted). 
views harassment, the employer may be able to convey to its workers the extent to which such behavior will not be tolerated.

\section{Changing the Workplace Culture by Creating Concrete Negative Ramifications for Misbehavior}

In addition to modeling a serious and sober approach to workplace harassment, organizations can change their workplace cultures to make harassment less prevalent by creating significant and concrete negative ramifications for such misconduct. As one group of researchers has advised, "organizations need to spell out the stakes of what's to be lost with harassment." ${ }^{101}$ These researchers recommend linking such misbehavior to specified negative outcomes, and claim that highly publicized negative ramifications for harassers signal to employers and employees just what the stakes are related to their workplace behavior. ${ }^{102}$ They note, for example, the impact of television host Matt Lauer losing his reported \$20 million salary as a result of his alleged workplace sexual misconduct, asserting that "[w]hen the risks are tied to bank accounts and budgets, powerful people are more inclined to listen." ${ }^{103}$ Again, the EEOC has backed up this research, advising "at all levels, across all positions, an organization must have systems in place that hold employees accountable ... [by] ensur[ing] that those who engage in harassment are held responsible in a meaningful, appropriate, and proportional manner...." $" 104$

Publicizing the negative ramifications for harassment can further nudge a workplace toward cultural change. If employees know the risks for misbehavior and know about examples where those consequences have been implemented, they may think twice about engaging in such conduct. One attorney who leads sexual harassment training for his corporate clients has observed that top executives at the firms with which he works have grown more open to one-onone coaching, perhaps in part because recent headlines regarding workplace harassment have served as a reminder of the financial stakes associated with this

101. Mary Slaughter, Khalil Smith \& David Rock, The Brain Science That Could Help Explain Sexual Harassment, PSYCHOL. TODAY (Jan. 24, 2018), https:/www.psychologytoday.com/us/blog/yourbrain-work/201802/the-brain-science-could-help-explain-sexual-harassment [https://perma.cc/NW89$56 \mathrm{HW}]$.

102. See id:; Peter J. Henning, Taxpayers are Subsidizing Hush Money for Sexual Harassment and Assault, CONVERSATION (Nov. 5, 2017), https://theconversation.com/taxpayers-are-subsidizing-hushmoney-for-sexual-harassment-and-assault-86451 [https://perma.cc/PHQ8-VJXJ] (arguing that "[o]ne way to discourage corporate misconduct is to raise the cost of engaging in it").

103. Slaughter et al., supra note 101; see Greg Price, Matt Lauer Net Worth: Disgraced NBC Host Loses Huge Salary After Firing, NEwSwEEK (Nov. 29, 2017), https://www.newsweek.com/lauer-networth-salary-millions-

725524?lipi=urn\%3Ali\%3Apage\%3Ad_flagship3_pulse_read\%3BvagC5wteRHmb7xtnmRmJvg\%3D \% 3D [https://perma.cc/8DGN-2UBZ].

104. EEOC Task Force Report, supra note 11, at 31. 
behavior. ${ }^{105}$ In the view of this attorney, "[t]he economic reality of [workplace sexual harassment] is hitting home more than it ever has."106

In many employment settings, however, publicizing the negative ramifications of harassment seems to butt up against a culture of secrecy, where even those workers with a known record for inappropriate behavior find their misconduct shielded from public view. ${ }^{107}$ Sometimes this secrecy works to protect the company, whether from any legal consequences associated with employing the wrongdoer, or from the reputational harm resulting from not taking action sooner. ${ }^{108}$ Sometimes this secrecy may flow out of contractual obligations, such as when management quietly settles harassment claims brought by employees, simultaneously demanding confidentiality as part of any such settlement. ${ }^{109}$ Sometimes the secrecy flows directly out of the harasser's position of power, as seemed to be the case in Weinstein's situation. ${ }^{110}$ As previously noted, Weinstein reportedly enforced a code of silence throughout his company, barring any criticism that could harm the company's or leaders' reputations. ${ }^{111}$ Eliminating such imposed silence and making public any credible allegations of harassment can communicate to members of the organization (including those

105. See McGregor, supra note 64 .

106. Id. Of course, various privacy restrictions might prevent the public disclosure of specific examples of negative ramifications for harassment. For example, concerns about tort claims for invasion of privacy might restrict the disclosure of this information. See, e.g., Miles v. Boeing Co., 154 F.R.D. 112, 115 (E.D. Pa. 1994) (noting that "[a]lthough employment information regarding a competing candidate... is subject to discovery..., personnel files are confidential and discovery should be limited") (citation omitted). State statutes likewise seem to contemplate access to personnel information by the employees to whom such information relates, but not access by outsiders without an employee's permission (absent a subpoena or other court order). See, e.g., Cal. Lab. Code § 1198.5(a) (Deering 2019). Finally, a host of contractual restrictions-from settlement agreements containing confidentiality provisions to nondisclosure and/or non-disparagement agreements - might limit the employer's ability to make specific examples of harassment public. See, e.g., S.B. 1300, 2018 Leg., Reg. Sess. (Cal. 2019) (prohibiting employers in some circumstances from requiring employees to sign non-disparagement agreements that preclude employees from disclosing information about unlawful acts in the workplace, including sexual harassment).

107. See John B. Pryor, Sexual Harassment Proclivities in Men, 17 Sex Roles 269, 271 (1987) (citing research indicating that "sexual harassers typically have reputations for sexually exploitative behaviors").

108. See LaMagna I, supra note 7 (arguing that "[o]ne major reason why repeat offenders can continue harassing for years [is that s]ome employers are reluctant to share information about a sexual harasser because they are embarrassed it took them so long to fire him").

109. See Kari Paul \& Maria LaMagna, The Damaging, Incalculable Price of Sexual Harassment, MARKETWATCH (Jan. 9, 2018), https://www.marketwatch.com/story/as-harvey-weinstein-takes-a-leaveof-absence-heres-how-much-sexual-harassment-costs-companies-and-victims-2017-10-07

[https://perma.cc/BQE5-84JY] (hereinafter "LaMagna II") (quoting a law professor who suggests that "[w]hen alleged perpetrators are prominent at their companies, employers sometimes decide it's worth settling with alleged victims rather than getting rid of the perpetrator"); see, e.g., Kantor \& Twohey, supra note 1 (noting that there have been at least eight settlements between Weinstein and women who he has allegedly harassed).

110. See Farrow, supra note 1 (citing victim who posited that everyone in Hollywood knew about Weinstein's harassment “[b]ut everyone's too scared to say anything").

111. See Kantor \& Twohey, supra note 1. 
who might potentially engage in sexual misbehavior) that the organization takes seriously this type of misconduct and will not tolerate it within the workplace. ${ }^{112}$

To be sure, some research disputes the efficacy of using negative ramifications to try and change behavior, indicating instead that rewards or positive reinforcement play a larger role in encouraging individuals to undertake significant change. ${ }^{113}$ But even if "shaming" or "punishing" may not alter the behavior of an individual harasser, publicizing the negative consequences that flow from misbehavior might shift the culture within an organization as a whole: The public imposition of negative ramifications - particularly negative financial ramifications - upon those who engage in harassment demonstrates to an organization's employees and to the broader public that harassment is not part of the "patterns of accepted behavior" that form the culture in this particular workplace. ${ }^{114}$ Moreover, as potential targets and victims of harassment observe that their organization takes such behavior seriously by imposing negative consequences on employees who engage in such misconduct, they may be more willing to speak up themselves when faced with such inappropriate conduct. ${ }^{115}$ Thus, even if individual harassers find themselves personally unchanged by these negative consequences, those individuals may soon come to understand that they no longer fit within the culture of the organization that refuses to permit behavior such as theirs.

\section{Changing the Workplace Culture by Altering the Power Structure within an Organization}

In addition to modeling a serious and sober approach to harassment and implementing concrete negative ramifications for misbehavior, employers also can transform the culture of their workplace by modifying the broader power structure within their organization. Research bears out that the balance of power within an organization impacts the extent to which that organization's culture tolerates (and even encourages) harassment. As one set of researchers has observed, "harassment flourishes in workplaces where men dominate in management and women have little power." 16 These researchers likewise posit

112. See Elizabeth C. Tippett, Public Shaming of Workplace Harassers May Force Employers to Stop Protecting Them, CONVERSATION (Nov. 8, 2017), https://theconversation.com/public-shaming-ofworkplace-harassers-may-force-employers-to-stop-protecting-them-87139 [https://perma.cc/ZXD9EYXR]. Having corporations show public support for victims of harassment not only might minimize the instances of harassment, but also might minimize the negative impact on victims. See generally Slaughter et al., supra note 101 (noting that "cynicism from leadership regarding sexual misconduct can lead to what clinical psychologists refer to as 'institutional betrayal' - where the trauma of an assault is compounded by bureaucratic incompetence or opposition or indifference from management") (citation omitted).

113. See, e.g., Andersen, supra note 74 (positing that "[p]eople will change their behavior if they see the new behavior as easy, rewarding and normal.")

114. See id.

115. See Tippett, supra note 112.

116. Dobbin \& Kalev, supra note 65. 
that harassment arises in organizations where few women occupy "core" positions. ${ }^{117}$ Accordingly, companies could decrease harassment in their workplaces if they hired and promoted women in greater numbers. ${ }^{118}$

Researchers already have established that access to power alters the manner in which an individual thinks. In one study, researchers found that "elevated power increases the psychological distance that an individual feels from others." "119 Other studies have found that "powerful people consider others' perspectives less." ${ }^{120}$ Power increases individuals' anticipation of rewards while decreasing their perceptions of threat, ${ }^{121}$ "increases individuals' optimism in viewing risks" and heightens "their propensity to engage in risky behavior," 122 and "prompts people to perceive sexual interest" when none actually is present. ${ }^{123}$ Furthermore, individuals with greater access to power show greater likelihood to behave in an impulsive manner, which can manifest in such individuals violating workplace ethical rules. ${ }^{124}$ In one experiment, researchers observed "participants in power [taking] candy from children without blinking an eye." ${ }^{25}$ Examining findings like this, the EEOC Task Force Report observed "superstar status can be a breeding ground for harassment." 126

Without question, with his tremendous resources, broad networks of influence, and virtually limitless control within the Weinstein Company, Harvey Weinstein fell squarely into this description of the superstar employee. Moreover, if even only some of the accounts of Weinstein's inappropriate behavior are true, his behavior fits perfectly within the laundry list of traits noted above: He either never considered whether the women whom he accosted had any sexual interest in him, or mistakenly perceived interest despite its utter absence; he appeared to focus almost entirely on the "reward" (the sexual

\section{See id.}

118. See id. (observing that "[i]n industries and workplaces where women are well represented in the core jobs, harassment is significantly less likely to occur"); Miller, supra note 10 (noting that companies employing greater numbers of women in management experience less sexual harassment).

119. Pamela Smith \& Yaacov Trope, You Focus on the Forest When You're In Charge of the Trees: Power Priming and Abstract Information Processing, 90 J. OF PERSONALITY \& Soc. PsYCHOL., No. 4, 578, 578 (2006); see Slaughter et al., supra note 101 (discussing Smith \& Trope study).

120. Slaughter et al., supra note 101 (citations omitted); see Dacher Keltner, Sex, Power, and the Systems That Enable Men Like Harvey Weinstein, HARV. BuS. REV. (Oct. 13, 2017), https://hbr.org/2017/10/sex-power-and-the-systems-that-enable-men-like-harvey-weinstein [https://perma.cc/E7JB-YLDV] (observing that individuals in powerful groups may develop "empathy deficits" and be less able to read others' emotions and/or understand others' perspectives).

121. See Cameron Anderson \& Jennifer L. Berdahl, The Experience of Power: Examining the Effects of Power on Approach and Inhibition Tendencies, 83 J. OF PERSONALITY \& SOC. PsyCHOL., No. 6, 1362, 1373-74 (2002); see Slaughter et al., supra note 101.

122. Cameron Anderson \& Adam D. Galinsky, Power, Optimism, and Risk-Taking, 36 EUR. J. OF SOC. PSYCHOL., 511, 529 (2006); Slaughter et al., supra note 101.

123. Slaughter et al., supra note 101; see Keltner, supra note 120 (discussing how power can "manifest in inappropriate sexual behavior in male-dominated contexts").

124. Keltner, supra note 120; see EEOC Task Force Report, supra note 11, at 24 (asserting that "privilege can lead to a self-view that they are above the rules, which can foster mistreatment").

125. Keltner, supra note 120.

126. EEOC Task Force Report, supra note 11, at 24. 
conquest), while assuming that any "threat"-whether it be legal liability or bad publicity - would be dealt with by his vast staff of underlings; he manifested an inherent belief that he was "above the rules" that applied to everyone else. ${ }^{127}$ Weinstein's almost omnipotent presence within the company also ensured the absence of any real check on his behavior: The Weinstein Company's Board readily accepted excuses for his misdeeds, ${ }^{128}$ and the company's human resources department was described as "a place where you went to when you didn't want anything to get done... [b]ecause everything funneled back to Harvey." 129

Of course, simply altering the power structure within an organization will not serve as an automatic fix for the dynamics that contribute to sexual harassment at work. But, allowing women to fill more significant roles would give potential victims of workplace sexual misconduct (who are predominantly female $)^{130}$ more allies at the top of the corporate hierarchy, ${ }^{131}$ while also providing leaders who are "more likely to be watchfully present in the contexts in which the powerful abuse power."132 Moreover, placing women into positions of power can alter the workplace culture in a much more fundamental way, by more generally curbing the marginalization of women at work. ${ }^{133}$ The impact of such a shift in perception could be significant: Weinstein's own attorney, in endeavoring to explain her client's behavior, referred to Weinstein as "an old dinosaur learning new ways." 134 Perhaps shaking up the corporate hierarchy to increase the power and authority of women - and to remove power from men who abuse such authority-would more effectively drive home to "old dinosaurs" like Weinstein that misbehavior which might have gone unnoticed in the past no longer will be tolerated by those in power. ${ }^{135}$

127. See Farrow, supra note 1; Kantor \& Twohey, supra note 1.

128. See Kantor \& Twohey, supra note 1.

129. Farrow, supra note 1 (quoting a former female executive at the Weinstein Company).

130. See Chatterjee, supra note 8 (reporting that (1) $81 \%$ of women, compared to $43 \%$ of men, claim to have experienced some form of sexual harassment, and (2) $38 \%$ of women have report being harassed in the workplace); $c f$. Wan, supra note 88 (noting that it is "almost always men doing the harassing").

131. See EEOC Task Force Report, supra note 11, at 28 (citing the existence of significant power disparities in a workplace as a risk factor leading to harassment); $c f$. id. at 26 (observing that "sexual harassment of women is more likely to occur in workplaces that have primarily male employees").

132. Keltner, supra note 120.

133. See Jessica Fink, Gender Sidelining and the Problem of Unactionable Discrimination, 29 STAN. L. \& POL'Y REV. 57, 100-03 (2018) (citations omitted).

134. Kantor \& Twohey, supra note 1.

135. This effort to alter the power structure within an organization and to include women in greater numbers must involve more than a mere image or illusion of promoting and valuing women. Rather, there must be substance behind this position, actually providing women with meaningful power. Indeed, Weinstein himself has long positioned himself as a "liberal lion [and] a champion of women," see Kantor \& Twohey, supra note 1, even producing a documentary on campus sexual assault and helping to endow a faculty chair at Rutgers University in Gloria Steinem's name, see id. Yet without providing women within his organization with actual power - the power to model appropriate treatment of women in the workplace and to successfully demand change in the face of inappropriate conduct — such shallow nods to gender equality lack any real impact. See id. (observing that, simultaneous with Weinstein's humanitarian efforts, “[d]ozens of Mr. Weinstein's former and current employees, from assistants to top 


\section{USING THE FAITHLESS SERVANT DOCTRINE AND OTHER DISGORGEMENT STRATEGIES TO Hit HARASSERS WHERE IT HURTS (I.E., IN THEIR WALLETS)}

While multiple experts seem to agree that a key to decreasing sexual harassment at work involves changing the culture of a workplace to render such behavior intolerable, uncertainty remains regarding how best to effectuate such a cultural change. What specific steps can organizations take to model a serious and sober approach to harassment, to create concrete negative ramifications for such behavior, and/or to alter the broader power structure in the workplace? When carefully-worded harassment policies and sophisticated harassment training sessions fail, might there be an opportunity to use a less conventional approach to drive this message home to an organization's employees - both to perpetrators of harassment and to those in the workplace who merely observe such behavior? Faced with such daunting questions, this paper examines one novel possibility: whether a fairly unusual approach to addressing sexual harassment at work might have an impact on reducing this phenomenon. Specifically, this paper asks whether a little-discussed doctrine of remedies law called the faithless servant doctrine, along with similar compensation forfeiture tools, could present one way for companies to convey more effectively to their employees their refusal to countenance harassment at work, perhaps altering the overall culture of the workplace.

At its most basic level, the faithless servant doctrine holds that "an agent is entitled to no compensation for conduct which is disobedient or which is a breach of his or her duty of loyalty." 136 The duty of loyalty "requires fiduciaries to exercise their authority in a good-faith attempt to advance corporate purposes ... [and] prohibits fiduciaries from putting their own interests ahead of those of the shareholders." 137 The bad faith that forms the basis of a duty of loyalty breach "can result from any emotion [that] may cause a director to [intentionally] place his own interests, preferences or appetites before the welfare of the corporation, including hatred, lust, envy, revenge." ${ }^{138}$ For example, an executive may breach their duty of loyalty by consciously causing the corporation to violate the law, ${ }^{139}$ or by failing to exercise proper oversight over the corporation. ${ }^{140}$ Under the

executives, said they knew of inappropriate conduct while they worked for him [but o]nly a handful said they ever confronted him").

136. Van Arsdale, supra note $13, \S 2$.

137. Daniel Hemel \& Dorothy S. Lund, Sexual Harassment and Corporate Law, 118 Colum. L. REV. 1583, 1629 (2018) (hereinafter "Hemel \& Lund II") (citations and internal quotations omitted); see also Kaye v. Rosefielde, 121 A.3d 862, 869 (N.J. 2015) (observing that "[a]n employee must not while employed act contrary to the employer's interest" (citations and internal quotations omitted)).

138. Meena Yoo, Corporate Governance in a Post-Weinstein Era, FordHAM J. OF CORP. \& FIN. L. (Jan. 6, 2018), https://news.law.fordham.edu/jcfl/2018/01/06/corporate-governance-in-a-post-weinsteinera [https://perma.cc/6UGR-22J9] (citations and internal quotations omitted).

139. See Hemel \& Lund II, supra note 137, at 1630.

140. See id.; Hemel \& Lund I, supra note 32 (describing potential for board liability for breach of the duty of loyalty for exposing a company to unreasonable financial risk, whether negligently or with intent). 
faithless servant doctrine, these types of disloyal or deceitful employees must forgo their compensation during any period of faithlessness. ${ }^{141}$

Importantly, the faithless servant doctrine is grounded in restitution, not in compensation. ${ }^{142}$ Therefore, its focus is not on making a plaintiff-employer whole from its losses, but rather on disgorging the defendant-employee's wrongful gain. ${ }^{143}$ Moreover, while the idea of forfeiture actually dates back centuries, with deep roots in the law of equity, ${ }^{144}$ modern courts have applied these forfeiture concepts with some frequency not just to ensure that an employer is made whole with respect to any loss caused by an employee's breach of her fiduciary duties, ${ }^{145}$ but also to deter any further disloyalty by the employee, by disgorging any profits that might have flowed out of such a breach. ${ }^{146}$

While the contours of the faithless servant doctrine can vary significantly from one jurisdiction to the next, ${ }^{147}$ and while some jurisdictions might refer to the remedy more generally as "disgorgement" or "forfeiture," rather than as the "faithless servant doctrine," 148 the underlying notion of using compensation forfeiture to respond to wrongful conduct by employees who breach their fiduciary duties remains a theme throughout this area of the law. Applied across a broad range of cases and circumstances - whatever name may be used to reference the doctrine- these tools represent powerful means of addressing

\footnotetext{
141. Van Arsdale, supra note 13, $§ 2$.

142. See Manning Gilbert Warren III, Equitable Clawback: An Essay on Restoration of Executive
} Compensation, 12 UnIV. PA. J. BuS. L. 1135, 1136 (2010).

143. See Dobbs, supra note 14, § 4.1(1) (describing restitution as "a return or restoration of what the defendant has gained in a transaction"); More on Faithless Servants, WORKPLACE PrOF BLOG (Jan. 29, 2010), http://lawprofessors.typepad.com/laborprof_blog/2010/01/more-on-faithless-servants.html [https://perma.cc/4829-PGSM] (characterizing forfeiture as "a one-way restitution claim since the employee can't seek to recover in quantum meruit the reasonable value of the services he did render"); FRIEBERGER HABER LLP, What is the Faithless Servant Doctrine and Why is it a Potent Weapon for Employers?, (Nov. 29, 2016), https://fhnylaw.com/faithless-servant-doctrine-potent-weapon-employers/ [https://perma.cc/6GFQ-VH4V] (observing that, under the faithless servant doctrine, a breaching employee "must forfeit all compensation earned since the first date of employment, even though the employee's services may have otherwise benefitted the employer ...,", and characterizing any value that an employee may have provided to the employer through his or her loyal services as "irrelevant").

144. See George P. Roach, Compensation Forfeiture: Stacking Remedies Against Disloyal Agents and Employees, 47 ST. MARY's L.J. 249, 251 (2015) (observing that "[t]he principles underlying compensation forfeiture against disloyal fiduciaries date back in the law of equity to before 1600 ").

145. See Dobbs, supra note $14, \S 3.1$ (observing that "[t]he stated goal of [] damages[] is compensation of the plaintiff for legally recognized losses ... [in] an effort to put the plaintiff in his or her rightful position"); Roach, supra note 144, at 307-08 (discussing the goal of disgorgement which is "compensation, punishment, and deterrence") (citations omitted).

146. See Karen Rubin, Disloyal GC's Can Be Required to Disgorge Salary, Says NJ High CourtEven if No Economic Harm, LAW FOR LAWYERS TODAY (Nov. 5, 2015), https://www.thelawforlawyerstoday.com/2015/11/disloyal-gcs-can-be-required-to-disgorge-salary-saysnj-high-court/ [https://perma.cc/GW8G-PG4A] (discussing deterrent effect of disgorgement).

147. See infra § III.B.2.

148. See Roach, supra note 144, at 304-09 (noting that "[c]ompensation forfeiture is sometimes equated to the faithless servant doctrine...," and that "forfeiture is a remedy in equity that resembles disgorgement as they both share the driving rationale of denying unjust enrichment to a disloyal fiduciary"). 
fiduciary breaches by workers. ${ }^{149}$ Moreover, while many cases that apply these principles deal with financial wrongdoing and/or other instances of usurping corporate opportunities, there is at least some precedent for disgorging an employee's compensation when their breach consists of sexual misconduct at work.

To be sure, applying the faithless servant doctrine to a situation involving sexual harassment by an employee would require, as a predicate matter, establishing that engaging in sexual harassment actually constitutes a breach of the employee's fiduciary duties. Courts admittedly have reached mixed conclusions in this respect. In Pozner v. Fox Broadcasting Company, the court asserted that there was no precedent for allowing "sexual harassment by an executive, without more, [to form] the basis of a breach of the duty of loyalty claim." 150 Other courts, however, have seemed somewhat more amenable to this argument. ${ }^{151}$ More importantly, engaging in sexual harassment seems to fit squarely within how courts have conceived of fiduciary duty breaches more broadly: If courts assume that acting in a manner that cuts against the company's best interests constitutes a breach of fiduciary duty, ${ }^{152}$ then an employee who sexually harasses employees or others connected with the company clearly seems to fall within such a prohibition. ${ }^{153}$

As discussed in greater detail below, however, the faithless servant doctrine and other compensation forfeiture tools may be a fairly clumsy way of addressing sexual harassment in some contexts: While some aspects of these doctrines render them an appropriate response to misconduct like Weinstein's, other aspects of the Weinstein scandal-particularly, the Weinstein Company's own apparent complicity in Weinstein's wrongdoing-raise significant questions about the applicability of these powerful tools to bad actors like Weinstein. Where the employer who would benefit from any compensation disgorgement ignored (and perhaps even permitted) the underlying breach of fiduciary duties

149. Notably, while it sometimes is assumed that only high-level employees within an organization owe fiduciary duties to an employer, in fact all employees - even lower level workers - may be held to have a duty of loyalty toward their employers. See J. Robert Smith, Fiduciary Duties of Employees, HOLLAND \& HART: FIDUCIARY LAW BLOG (Nov. 3, 2014), https://www.fiduciarylawblog.com/2014/11/fiduciary-duties-of-employees.html [https://perma.cc/684TXVB7] (observing that even "low-level" employees owe fiduciary duties to their employer); see Eckard Brandes, Inc. v. Riley, 338 F.3d 1082, 1086 (9th Cir. 2003) (holding that even "low-level" or "ordinary" employees may have duty of loyalty toward employer (citations omitted)).

150. Pozner v. Fox Broadcasting Company, 74 N.Y.S.3d 711, 714 (N.Y. App. Div. 2018).

151. See Hemel \& Lund II, supra note 137, at 1623-25 (discussing derivative action alleging breach of duty of loyalty brought against company and former CEO based upon former CEO's sexual misconduct and direction that the company expend resources to further his sexual relations); see also id. at 1624 (quoting the Chancellor's observation that "[t]he complaint clearly . . . states a sufficiently colorable claim that Hewitt breached his fiduciary duty by engaging in conduct that led to his termination" (citation omitted)).

152. See Yoo, supra note 138.

153. See id. (observing that "[b]y sexually harassing employees and potential employees, Weinstein abused his position of power ... [and $\mathrm{h}$ ] is conduct can only be described as self-serving at the risk of the Weinstein Company’s business interests") (citations omitted). 
to take place, as the Weinstein Company may have done here, there may be serious concerns about applying these forfeiture principles without some significant modifications that would divert any gains away from the complicit employer and toward the victims of the sexual misconduct and/or the company's shareholders.

\section{A. Astra, USA v. Bildman: A Case Study in the Faithless Servant Doctrine Applied to the Sexual Harassment Context}

Perhaps more than any other case in which the faithless servant doctrine has been applied, the 1981 case of Astra, USA v. Bildman demonstrates the power of this doctrine to respond to high-level executives like Harvey Weinstein who engage in sexual and other misconduct at work. ${ }^{154}$ In 1981, Astra Pharmaceuticals ("Astra") hired Lars Bildman to serve as its president and chief executive officer, as well as to serve as a member of the board of directors of two of its subsidiaries. ${ }^{155}$ For more than 15 years, Bildman performed well in his position, successfully implementing corporate strategy, effecting significant management changes, and overseeing substantial growth within the company. ${ }^{156}$ During the final five years of his employment, "[f]rom 1991 through 1996, Astra's overall profit met or exceeded" established goals, and Bildman's compensation unsurprisingly increased. ${ }^{157}$

In late 1995, Astra learned of allegations that Bildman and other members of Astra senior management had been engaged in workplace sexual harassment. ${ }^{158}$ Among the charges that eventually emerged were allegations by a former secretary who had received a payoff and left the company after Bildman had forced her into sexual relations, ${ }^{159}$ as well as settlement payments to at least three other female employees who alleged that Bildman had sexually harassed them. ${ }^{160}$ In addition to denying any allegations of harassment, ${ }^{161}$ Bildman refused to cooperate with Astra's investigation and took various steps to stymie the investigation's progress, including by asking former and current Astra employees to deny that he ever had acted improperly and directing a colleague to shred corporate documents and erase company computers. ${ }^{162}$

Despite Bildman's efforts at obstruction and cover-up, reports ultimately indicated a dozen instances of women being fondled or solicited for sexual favors by Bildman or other Astra executives during Bildman's fifteen-year tenure at 
Astra ${ }^{163}$ leading the Astra Board of Directors to rescind Bildman's employment contract and terminate him for cause. ${ }^{164}$ The EEOC also filed a complaint against Astra alleging a pattern and practice of sexual harassment against female workers at the company - a complaint that Astra ultimately settled (without admitting liability) by establishing a $\$ 9,850,000$ victim compensation fund. ${ }^{165}$ Astra subsequently sued Bildman on a number of grounds, including fraud, breach of fiduciary duty, and breach of the duties of good faith and loyalty. ${ }^{166}$ After the jury found Bildman liable for, inter alia, breach of fiduciary duty, the trial court ordered an evidentiary hearing to determine whether Bildman's compensation during the five year period of his disloyalty exceeded the value of the services that he had provided to Astra, thus justifying the disgorgement of his pay. ${ }^{167}$ When the trial judge declined to order such disgorgement, Astra appealed, arguing that the court should require Bildman to forfeit all of the salary and bonuses that he received during the period in which he was disloyal to the company-an amount in excess of $\$ 5$ million. ${ }^{168}$

On appeal, the Supreme Judicial Court of Massachusetts, applying New York Law, held that the faithless servant doctrine should require Bildman to forfeit all of the salary and bonuses that he received during this five-year period. ${ }^{169}$ The court explained that "an agent is held to ... utmost fidelity in his dealings with his principal, and if he acts adversely to his employer in any part of the transaction ...., it amounts to such a fraud upon the principal, as to forfeit any right to compensation for services." ${ }^{\text {"170 }}$ Relying upon additional precedent, the court observed that "one who owes a duty of fidelity to a principal and who is faithless in the performance of his or her services is generally not entitled to recover compensation, whether commissions or salary." ${ }^{171}$ Moreover, the court observed that this forfeiture would apply regardless of the value of the services that the employee might have provided during the period of the disloyalty. Indeed, the court declared that a faithless servant should lose the right to recover compensation, "even if he otherwise performed valuable services for the principal." 172

\section{B. Disgorging Compensation Beyond Astra: Additional Examples of}

\footnotetext{
163. See id. at 43 .

164. See id.

165. See id.

166. See id. at 44.

167. See id. at $44-45$.

168. See id. at $45-46$.

169. See id. at 46 .

170. Id. at 47 (citations, alterations, and quotation marks omitted).

171. Id. (citation and quotation marks omitted); see also Soam Corp. v. Trane Co., 608 N.Y.S.2d 177, 178 (N.Y. App. Div. 1994) ("An agent is held to utmost good faith in his dealings with his principal, and forfeits any right to compensation for his services if he acts adversely to his employer.").

172. Astra USA, 914 N.E.2d at 47; see also id. ("Nor does it make any difference that the services were beneficial to the principal, or that the principal suffered no provable damage as a result of the breach of fidelity by the agent.") (citation and quotation marks omitted).
} 


\section{Compensation Forfeiture ${ }^{173}$}

While Astra provides one illustration of the faithless servant doctrine applied to sexual misconduct, various other cases have applied this sort of restitutionary theory to disgorge compensation from wrongdoing employees more generally. While some courts specifically refer to the faithless servant doctrine as the basis for this disgorgement, others refer to "forfeiture" or "disgorgement" to achieve the same result: the paying back of some or all compensation received by an employee who has breached his or her fiduciary duties. ${ }^{174}$

\section{Cases Applying Compensation Forfeiture to Fiduciary Breaches}

In a variety of cases, courts have applied concepts of compensation forfeiture to disgorge the salary and/or benefits of faithless fiduciaries. In Phansalkar v. Andersen Weinroth \& Co., an investment banker was found to have breached his duties of loyalty and good faith by failing to disclose substantial compensation and opportunities that he had received through serving on various outside boards of directors. ${ }^{175}$ Rather than focus on the extent to which the banker's misconduct may have harmed his former employer-what would have been the focus of a compensatory damages inquiry ${ }^{176}$ - the Second Circuit Court of Appeals required the banker to forfeit all compensation that he received from his employer following the date upon which his disloyalty began. ${ }^{177}$ In so doing, the court explicitly rejected the trial judge's decision to only require the banker to forfeit part of his compensation in response to his breach. ${ }^{178}$ Instead, the Second Circuit held that New York law would require a complete disgorgement of all compensation that the banker had received following the date upon which his disloyalty began. ${ }^{179}$ According to the Second Circuit, "[i]t does not make any difference that the services rendered [by the breaching employee] were beneficial to the principal, or that the principal suffered no provable

173. This section includes a description of how various jurisdictions have applied concepts of compensation disgorgement and/or forfeiture, with some courts adopting more stringent approaches than others. It is difficult to discern whether there is any "majority view" regarding the best manner in which to apply these concepts (and, if so, what that majority view might be). Nonetheless, as described in greater detail herein, these compensation disgorgement and/or forfeiture principles would seem to apply to misconduct like Weinstein's even in jurisdictions that adopt a more rigid or limited view of these doctrines. See infra notes 217-20, 239 and accompanying text, § III.C.

174. Other courts discuss this disgorgement in terms of "equitable clawback." See, e.g., Warren, supra note 142, at 1136 (equating "equitable clawback" with the forfeiture of compensation inherent in the Faithless Servant Doctrine"). Agency principles also reflect notions of disgorgement, see RESTATEMENT (SECOND) OF AGENCY § 469 (AM. LAW INST. 1958), and the Restatement of Employment Law similarly echoes this view, see RESTATEMENT OF EMPLOYMENT LAW $§ 9.09$ (c) (AM. LAW. INST. 2019).

175. 344 F.3d 184, 189-95 (2d Cir. 2003).

176. See supra note 145 and accompanying text.

177. See Phansalkar, 334 F.3d at 208.

178. See id. at 199-200.

179. See id. at 200. 
damages as a result of the breach of fidelity ...." ${ }^{180}$ Rather, the employee's breaches of loyalty and good faith toward his employer themselves were sufficient to warrant a forfeiture of compensation. ${ }^{181}$

In Enstar v. Grassgreen, Richard Grassgreen, a senior executive at KinderCare, Inc., was found liable for breach of fiduciary duties related to a wide array of financial improprieties that occurred over a five year period of time. ${ }^{182}$ After the jury awarded compensatory and punitive damages to Grassgreen's former employer initially totaling almost $\$ 20$ million, ${ }^{183}$ the Alabama federal district court confronted the equitable issues in the case, ${ }^{184}$ including Enstar's demand for forfeiture and recovery of all compensation that Grassgreen received during the entire five-year period of his breach of fiduciary duties. ${ }^{185}$ The court held that Grassgreen should be required to forfeit all of the compensation paid to him by Enstar during this period - an amount that totaled over $\$ 5.4$ million. ${ }^{186}$ In reaching this conclusion, the court rejected Grassgreen's argument that the court should impose only a partial forfeiture because "regardless of what he may have done wrong, he worked diligently on behalf of the corporation and the corporation profited from his work." ${ }^{187}$ Instead, the court relied upon prior 10th Circuit authority which had held that "an agent who acts for his own benefit is not entitled to compensation which otherwise would be due him ..., even if he thinks his actions will benefit the principal." ${ }^{188}$ In the court's view, applying such a stringent remedy to a breaching fiduciary like Grassgreen would emphasize the need for corporate officers and directors to execute their duties appropriately, in the best interests of the company. ${ }^{189}$

In Kaye v. Rosefielde, the Supreme Court of New Jersey similarly indicated that the disgorgement of a faithless fiduciary's compensation could constitute a proper remedy for a breach of fiduciary duty. ${ }^{190}$ In Kaye, the defendant-a former chief operating officer and de facto general counsel for the plaintiff- not only engaged in various acts of financial misconduct during his employment with the

180. Id. (citations and quotation marks omitted).

181. See id

182. 812 F. Supp. 1562, 1565-71 (M.D. Ala. 1993); see also Roach, supra note 144, at 256-61.

183. See Enstar, 812 F. Supp. at 1569 . Specifically, the jury set compensatory damages at just over $\$ 1.9$ million and initially awarded $\$ 18$ million in punitive damages, see id., an amount that the court remitted to $\$ 10$ million, see $i d$. at 1582 .

184. See Dobbs, supra note $14, \S 2.6(2)$ (noting general rule that right to jury trial applies only to "common law" actions and not to equitable suits); see also Enstar, 812 F. Supp. at 1571 (noting that "the parties agreed [these] were not claims for which a right to jury trial existed").

185. See Enstar, 812 F. Supp. at 1571.

186. See id. at 1575 .

187. Id. at 1573 .

188. Id.

189. See id. at 1574 (deeming it "of crucial importance to the economic well-being of this country for corporate officers and directors to understand without question that in the discharge of the duties of their offices they must subordinate their personal interests to the interests of the corporation which they serve").

190. 121 A.3d 862, 873-74 (N.J. 2015). 
plaintiff, but also made multiple inappropriate sexual advances toward colleagues, thus subjecting the plaintiff to a risk of sexual harassment liability. ${ }^{191}$ In describing the ways in which the defendant breached his duty of loyalty, the trial court specifically cited, in addition to the defendant's financial self-dealing, his "inappropriate conduct toward female employees." 192 Reversing the trial court, the New Jersey Supreme Court held that disgorgement of some portion of the defendant's compensation during the periods of his disloyalty might be appropriate. ${ }^{193}$ In reaching this conclusion, the Kaye court specified the factors that courts should take into account in determining whether-and to what extent - disgorgement should apply to the compensation of a disloyal fiduciary: ${ }^{194}$ Courts should consider "the employee's degree of responsibility and level of compensation, the number of acts of disloyalty, the extent to which those acts placed the employer's business in jeopardy, and the degree of planning to undermine the employer that is undertaken by the employee." 195

Thus, precedent across several jurisdictions supports responding to breaches of fiduciary duty by disgorging at least some of the compensation of the breaching employee. ${ }^{196}$ While by no means the "law of the land" when a court is faced with such misconduct - these cases admittedly serve as isolated examples of this approach - these disgorgement principles represent a powerful (if somewhat novel) way of dealing with fiduciary breaches. Moreover, while the vast majority of breaches that have triggered this disgorgement have involved some financial impropriety by an employee, cases like Astra and Kaye make clear that this remedy may also apply when the breaching employee has engaged in egregious workplace sexual harassment.

\section{The Varying Contours of Compensation Disgorgement}

While various courts have turned to compensation forfeiture to address wrongdoing by a fiduciary, different courts have adopted different rules in

\section{Id. at $864-66$.}

192. Id. at 865 .

193. See id. at 874-75. Notably, in reaching this conclusion, the New Jersey Supreme Court did not specifically refer to the defendant's sexual misconduct as the basis for this remedy, but rather appeared to rely on the defendant's misconduct more broadly. See id.

194. Id. at 874 .

195. Id.

196. For additional examples of cases applying compensation disgorgement as a remedy, see, e.g.,William Floyd Union Free Sch. Dist. v. Wright, 877 N.Y.S.2d 395 (N.Y. App. Div. 2009) (allowing forfeiture of all of defendants' compensation, including by relieving employer of obligation to pay defendants' health, life and dental insurance premiums, after defendants engaged in theft and embezzlement); Bon Temps Agency Ltd. v. Greenfield, 445 N.Y.S.2d 981 (N.Y. App. Div. 1992) (endorsing compensation forfeiture against manager at placement agency who breached fiduciary and contractual duties and observing that "a disloyal employee is not entitled to receive compensation, whether commissions or salary") (citations and internal quotations omitted); Soam Corp. v. Trane Co., 608 N.Y.S.2d 177, 178 (N.Y. App. Div. 1994) (refuting characterization of compensation forfeiture as an 'unconscionable penalty' by observing that New York law "mandates the forfeiture of all compensation, whether commissions or salary, where, as here, one who owes a duty of fidelity to a principal is faithless in the performance of his services") (citations omitted). 
defining the contours of when and how to disgorge compensation from faithless employees.

\section{a. Differing views regarding the amount of harm that an employer must suffer in order to trigger disgorgement}

One area in which courts differ in applying disgorgement relates to the degree of harm that an employer must suffer before the court will disgorge compensation from a breaching fiduciary. Some courts have held that an employer need not establish proof of any direct damage or loss arising out of the employee's faithless performance; proof of the employee's disloyalty alone serves as a sufficient bass for the forfeiture of compensation. ${ }^{197}$ Indeed, in the view of some courts, the fact that an employer actually profited from an employee's work during the period of the employee's disloyalty will not prevent or limit the application of disgorgement. ${ }^{198}$ In Astra, for example, during the period of Bildman's misconduct, the overall profits of the company that Bildman oversaw met or exceeded its established goals. ${ }^{199}$ Yet in allowing the disgorgement of Bildman's compensation, the court observed that the faithless servant doctrine requires an employee to forfeit his compensation "even if he otherwise performed valuable services for the principal. ${ }^{200}$ In the court's view, "[n]or does it make any difference that the services were beneficial to the principal, or that the principal suffered no provable damage as a result of the breach. ..."201

The Enstar court mirrored this analysis, emphatically dismissing the employee's arguments that "his conduct... caused very little, if any, actual damage to the corporation" 202 and that his employer actually had made money from the investments that formed the basis of the employee's breach. ${ }^{203}$ To the contrary, the court deemed irrelevant to its forfeiture analysis any proof regarding the damage that the company may or may not have suffered as a result of the employee's breach. ${ }^{204}$ According to the court, it could no more question whether Grassgreen's conduct had harmed his former employer then it could

197. See Van Arsdale, supra note 13, $\S \S 2,8$; see also Feiger v. Iral Jewelry, Ltd., 363 N.E.2d 350, 351 (N.Y. 1977) ("Nor does it make any difference that the services were beneficial to the principal, or that the principal suffered no provable damage as a result of the breach of fidelity by the agent.") (citations omitted); Phansalkar v. Andersen Weinroth \& Co., 344 F.3d 184, 200 (2d Cir. 2003); James R. Carroll \& Jason C. Weida, Faithless Servants Beware: Massachusetts Forfeiture Law is More Severe Than Astra USA, Inc. v. Bildman Might Suggest, Boston BAR J. 7, 9 (2010).

198. See Feiger, supra note 198, at 351; Phansalkar, supra note 198, at 200.

199. Astra USA, Inc. v. Bildman, 914 N.E.2d 36, 40 (Mass. 2009).

200. Id. at 47 .

201. Id. (citations and quotations marks omitted).

202. Enstar Grp., Inc. v. Grassgreen, 812 F. Supp. 1562, 1574 (M.D. Ala. 1993).

203. See id.

204. See id. 
speculate regarding the benefits that Enstar would have accrued had Grassgreen faithfully performed his duties. ${ }^{205}$

The court in Kaye v. Rosefielde reached a similar conclusion with respect to the lack of any need for an employer to prove damages as a precursor to disgorgement. ${ }^{206}$ In allowing the disgorgement of the employee's salary in Kaye, the court observed, "the remedy of equitable disgorgement is available to a trial court even absent a finding that the employer sustained economic loss by virtue of the employee's disloyal conduct." ${ }^{207}$ Rather than viewing disgorgement as a way of making the employer whole for any economic loss caused by the breaching employee, the court seemed to view this remedy as being directed more toward altering the behavior of disloyal employees. ${ }^{208}$ Citing the possible deterrent impact of this remedy, the court noted "its availability signals [to] agents that some adverse consequences will follow a breach of fiduciary duty."209

Other courts, however, adhere to a more limited view, disgorging an employee's compensation only when the employer can establish that the employee's breach actually caused damage to the employer, ${ }^{210}$ or when an employee's disloyalty is related to his or her job duties. ${ }^{211}$ In Sanders v. Madison Square Garden, L.P., the New York Knickerbockers ("Knicks") basketball team claimed that a former employee who previously held various high-level marketing positions had been engaged in tax fraud and/or had been operating an outside business during her employment by the Knicks. ${ }^{212}$ The team subsequently sought to use the faithless servant doctrine to disgorge all of the compensation that the employee had received during the period in which she allegedly engaged in these wrongful activities. ${ }^{213}$ In denying the team's motion for leave to amend its answer to assert a counterclaim against the employee for breach of fiduciary duty, a New York federal district court observed that "neither operating an outside business nor unethical conduct unrelated to employment violates the faithless servant doctrine unless such business or behavior adversely affects the

\footnotetext{
205. See id.

206. 121 A.3d 862, 864-65 (N.J. 2015).

207. Id.

208. See id. at 873.

209. Kaye, $121 \mathrm{~A} .3 \mathrm{~d}$ at 873 (citations and internal quotations omitted); see Rubin, supra note 146 (characterizing the Kaye case as one "that's bound to scare in-house counsel...").

210. See, e.g., Hartford Elevator, Inc. v. Lauer, 289 N.W.2d 280, 287 (Wis. 1980) (holding that "whether the agent should be denied all or any part of his compensation ... depends on consideration and evaluation of the relevant circumstances ... includ[ing] . . the loss, expenses and inconvenience caused to the employer by the employee's breach ...."); Sanders v. Madison Square Garden, L.P., No. 06 Civ. 589(GEL), 2007 WL 1933933, at*4 (S.D.N.Y. July 2, 2007) (declining to apply Faithless Servant Doctrine where employer "conspicuously fails to identify any way in which it suffered any such damage...").

211. See Sanders, 2007 WL 1933933, at*7.

212. Id. at $* 1-2$.

213. See id. at *3. Specifically, Sanders had brought a discrimination suit against the Knicks, and the Knicks asserted the Faithless Servant Doctrine as part of a counterclaim against Sanders, having discovered evidence of her alleged wrongful conduct during discovery related to Sanders' lawsuit. See id.
} 
employee's job performance." ${ }^{214}$ Here, the court observed, the employer had failed to present any evidence that Sanders' alleged misconduct negatively impacted her performance. ${ }^{215}$ Instead, the court explicitly distinguished Sander's misconduct from that which had supported complete disgorgement in Phansalkar, finding that - unlike the wrongdoing in Phansalkar-any alleged misconduct by Sanders did not "permeate the employee's service in its most material and substantial part." 216

Even in these more restrictive jurisdictions, however, Weinstein's conduct undoubtedly would satisfy the requirement that an employer establish damages from an employee's breach of fiduciary duties; the Weinstein Company clearly suffered tremendous harm as a result of Weinstein's misbehavior. In fact, one need not speculate regarding the potential harm that Weinstein's conduct caused to the Weinstein Company: Within weeks of the initial disclosures regarding his behavior, one of the company's largest creditors, AI International Holdings, purportedly demanded an immediate repayment of a $\$ 45$ million loan that it had made to the Weinstein Company, and other parties that traditionally had worked with the Weinstein Company-such as Apple and Amazon-distanced themselves from the company. ${ }^{217}$ Within months, this once-multi-million dollar company faced financial ruin and a raft of litigation. ${ }^{218}$

\section{b. Differing views regarding the amount of compensation that an employer can disgorge}

Different jurisdictions also have adopted differing views regarding the amount of compensation that an employer can disgorge when faced with disloyalty by an employee. Some courts require a faithless servant to forfeit all compensation that he or she received once the disloyalty commenced, ${ }^{219}$ or for the entire period during which the employee's disloyalty occurred. ${ }^{220}$ Such courts

214. Id. at *4 (citations omitted); see id. at*7 (finding Sanders' alleged misconduct "[was] so far removed from [her] job responsibilities that it cannot be said that the misconduct 'substantially' interfered with her job performance").

215. Id. at *4.

216. See id. at *5 (citing Phansalkar v. Andersen Weinroth \& Co., 344 F.3d 184, 203 (2nd Cir. 2003)). Similarly, in Feiger v. Iral Jewelry, the highest New York state court rejected an employer's effort to disgorge commissions from an employee who took initial steps to start a competitive business, noting that plaintiff "never lessened his work on behalf of defendant and never misappropriated to his own use any business secrets or special knowledge ...." 363 N.E.2d 350, 351 (N.Y. 1977) (citations omitted).

217. See Hemel \& Lund I, supra note 32 .

218. See infra § III.D; supra notes 40-46 and accompanying text; Farrow, supra note 1 (opining that "Weinstein's behavior deeply affected the day-to-day operations of his companies").

219. See Van Arsdale, supra note 13, §§ 2, 12; cf. Astra USA, Inc., v. Bildman, 914 N.E.2d 36, 47 48 (Mass. 2009) (citing without endorsement cases articulating rule that "disloyal employees and agents forfeit all compensation ever received from the employer") (citations omitted).

220. See Carroll \& Weida, supra note 197, at 9 (citing cases that confirm a court's discretion to impose "total forfeiture during the period of breach") (citations omitted); Warren, supra note 142, at 1142 (observing that a majority of jurisdictions apply a "bright line rule that the agent must forfeit all compensation paid or payable over the entire period of the agent's disloyalty ..."); Astra, 914 N.E.2d at 
generally will not permit an employee to offset against the disgorged compensation the value of any benefits that might have flowed from the employee's work during the relevant period. ${ }^{221}$ In Astra, as noted above, the court deemed it appropriate to disgorge all of the compensation that Bildman earned during the five-year period of his disloyalty-1991 through 1996-despite evidence that Bildman successfully had performed his job duties during this period, generating profits for his employer. ${ }^{222}$ The Second Circuit reached a similar conclusion in Phansalkar, finding that the employer could disgorge all compensation earned by the disloyal employee during the period of the disloyalty, and expressly declining to limit disgorgement only to compensation for the specific tasks with respect to which the employee was disloyal. ${ }^{223}$

In Enstar, the Alabama federal court echoed this view, expressly rejecting Grassgreen's assertion that "it would not be equitable to require a total forfeiture of compensation because, regardless of what he may have done wrong, he worked diligently on behalf of the corporation and the corporation profited from his work." 224 Noting a desire to enforce corporate officers' and directors' duty of loyalty "as forcefully as possible," 225 the court disgorged "all salary, bonuses and other compensation that were paid to [Grassgreen] by his corporation while he was in breach of his duties"226 — an amount totaling almost $\$ 5.5$ million. ${ }^{227}$ Moreover, the Enstar court reached this conclusion while also acknowledging the almost \$2 million compensatory damages award already levied against Grassgreen, and while remitting the jury's $\$ 18$ million punitive damages award to a still-substantial $\$ 10$ million. ${ }^{228}$ In other words, the court did not seem to view the forfeiture of Grassgreen's salary and benefits as compensation for the employer, nor as "punishment" duplicative of the substantial punitive damages in this case. Rather, the court seemed to see this disgorgement as grounded in basic fairness and equity, citing with approval authority that characterized salary forfeiture following a breach as "required because the agent's services are not being "properly' performed." ${ }^{229}$ In other words, Grassgreen never truly "earned"

48 (noting New York Appellate Division decisions that "generally have limited the period of forfeiture to the period of the employee's disloyalty") (citations omitted).

221. See Warren, supra note 142, at 1142 (citations omitted); id. at 1136-37 (describing faithless servant doctrine as requiring an agent who breaches fiduciary duties to "forfeit any compensation for services rendered during the period of his breach even though part of those services may have been properly performed") (citation omitted).

222. 914 N.E.2d at 50-51; see also id. at 40.

223. Phansalkar v. Andersen Weinroth \& Co., 344 F.3d 184, 206-08 (2nd Cir. 2003); see id. at 208 (stating that "forfeiture cannot appropriately be limited to only some transactions in these circumstances, where the agreement calls for general compensation, and does not limit compensation to specific amounts paid for the completion of specific tasks").

224. Enstar Grp., Inc. v. Grassgreen, 812 F. Supp. 1562, 1573 (M.D. Ala. 1993).

225. Id. at 1574.

226. Id. at 1575 .

227. Id.

228. Id. at 1581-82.

229. Id. at 1574 (citations and quotation marks omitted). 
his compensation during the period of disloyalty and thus lacked any entitlement to such compensation.

For each of these courts, the justification for this total disgorgement seems to stem from a belief that such significant wrongdoing in one aspect of an employee's performance taints all other aspects of his or her employment—even those where the employee performed profitably for the employer. ${ }^{230}$ In this respect, disgorgement - as a restitutionary remedy - differs significantly from compensatory damages: While compensatory damages would focus primarily upon the specific losses experienced by the employer, ${ }^{231}$ disgorgement "was not developed to simply compensate the injured beneficiary for its losses, but to provide recovery for all ill-gotten gains of the breaching fiduciary as well as his salary and other compensation after the breach." ${ }^{\prime 232}$

Of course, not every court applying forfeiture principles agrees with this broad application of these doctrines. Instead, some courts take a more temperate view regarding the amount of compensation to disgorge, limiting forfeiture only to the compensation associated with those tasks that actually were performed in a disloyal manner. ${ }^{233}$ In such jurisdictions, the court may apportion the forfeiture of compensation and require disgorgement only as to salary or commissions with respect to which it finds disloyalty. ${ }^{234}$ In Sequa Corp. v. GBJ Corp., for example, the Second Circuit Court of Appeals cited a "possible relaxation of New York's strict rule demanding forfeiture of all of a faithless servant's compensation ... in favor of a rule of apportionment under which only the fees related to the 'specified items of work' as to which the agent acted faithlessly would be forfeited." ${ }^{235}$ Sequa, however, predates by several years the Second Circuit's more recent decision in Phansalkar, which allowed the complete disgorgement of a breaching fiduciary's compensation (with the cases decided in 1998 and 2003 , respectively). ${ }^{236}$ Thus, while some courts may appear to apply a more

230. See Warren, supra note 142, at 1142 (tracing rule imposing total disgorgement for period of breach to idea that "the agent's misconduct tainted or otherwise permeated his entire relationship with his principal from the original point of breach going forward").

231. See, e.g., Dobbs, supra note $14, \S 3.1$.

232. Warren, supra note 142, at 1137.

233. See Van Arsdale, supra note 13, §§ 2, 13 (citations omitted).

234. See id. $\S 13$ (citations omitted).

235. 156 F.3d 136, 147 (2nd Cir. 1998) (citation omitted); see also Kaye v. Rosefielde, 121 A.3d 862,874 (N.J. 2015) (noting that in applying factors to determine extent of disgorgement, a court need not disgorge the entirety of a wrongdoer's compensation, but rather may apportion disgorgement to the extent appropriate); Schneider v. Wein \& Malkin LLP, 2004 WL 2495843, at *18-19 (N.Y. App. Div. Nov. 1, 2004) (citations omitted) (discussing various factors to apply in determining amount of compensation to disgorge); $c f$. Richard F. Albert, Punishment Without Cause: Disgorgement and Forfeiture of Salary and Pensions, FORBES (Apr. 2, 2014), https://www.forbes.com/sites/insider/2014/04/02/punishment-without-cause-disgorgement-andforfeiture-of-salary-and-pensions/ [https://perma.cc/Y3Y8-6KTK] (discussing ruling in recent SEC enforcement action confirming that "disgorgement under the federal securities laws reaches only so much of a defendant's gains as are shown to be causally related to the fraud").

236. Compare Sequa, 156 F.3d, with Phansalkar v. Andersen Weinroth \& Co., 344 F.3d 184 (2nd Cir. 2003). 
moderate version of the faithless servant doctrine to reach only compensation directly tied to acts of disloyalty, ${ }^{237}$ other courts still seem to adhere to the harsher version of this doctrine..$^{238}$

Once again, while these jurisdictional differences may matter in many cases, as applied to Weinstein, their significance fades. Even if Weinstein were sued in a more restrictive jurisdiction that limited disgorgement only to the compensation associated with tasks that actually were performed disloyally, as discussed above, Weinstein's disloyalty seemed to permeate every aspect of his working life, from the way that he interacted with actresses to his use of underlings to cover up his misconduct to his persuading of the board to use company funds to pay off victims who dared to complain. ${ }^{239}$ One might argue that there was no aspect of Weinstein's working life that was cleansed of this misconduct. Accordingly, even in a jurisdiction that requires a close connection between any funds disgorged and any acts of misconduct, a plaintiff likely still would be able to reach most (if not all) of Weinstein's compensation.

\section{Hitting Harvey Where it Hurts: Harvey Weinstein as a Faithless} Servant

Examining this compensation forfeiture jurisprudence in light of the circumstances associated with the Weinstein controversy, one might wonder about the potential applicability of disgorgement to Weinstein. On the most obvious level, the factual parallels between the Weinstein matter and Astra are striking: Just as Bildman "used Astra as his personal checkbook and sexual fiefdom, in the process driving away employees, creating a corrosive corporate atmosphere, causing Astra actual loss, and leading to months of bad publicity about the company," 240 Weinstein likewise is alleged to have used the company as his sexual playground and to have strong-armed other workers into participating in his immoral and illegal behavior, all while enforcing a strict code of silence among everyone involved. ${ }^{241}$ More broadly, Weinstein's conduct arguably reflects the sort of fiduciary breach with respect to which courts have

237. While these jurisdictions potentially employ a more lenient application of the faithless servant doctrine and other forfeiture tools, courts in at least one such jurisdiction place the burden on the disloyal employee to establish the "value" of any services provided to the employer. See Carroll \& Weida, supra note 197 , at 9 .

238. See, e.g., Phansalkar, 344 F.3d at 208 ("Phansalkar is required to forfeit all compensation awarded to him after... the date upon which his disloyalty began."). Notably, the Restatement of Employment Law echoes the more modest approach, allowing an employer to disgorge the compensation paid to an employee who has breached his or her fiduciary duties only when "the employee's compensation cannot be apportioned between the employee's disloyal services and the employee's loyal services; and ... the nature of the employee's disloyalty is such that there is no practicable method for making a reasonable calculation of the harm caused the employer by the employee's disloyal services." RESTATEMENT OF EMPLOYMENT LAW $\S 9.09$ (c) (AM. LAW. INST. 2019)

239. See supra notes $29-35$ and accompanying text.

240. Astra USA, Inc. v. Bildman, 914 N.E.2d 36, 51, n. 30 (Mass. 2009).

241. See generally Farrow, supra note 1; Kantor \& Twohey, supra note 1; Faughnder et al., supra note 33; Hemel \& Lund I, supra note 32. 
ordered compensation forfeiture: While not a breach involving a more prototypical wrong like embezzlement or usurping corporate clients, "[p]resumably it counts as bad faith if a co-chairman were to use his position of power at the company to harass and sexually assault potential and actual employees while at the same time endangering the firm's reputation." ${ }^{242}$ Thus, Weinstein's conduct might well be seen as forming the underlying basis for a breach of fiduciary duty claim necessary to trigger a forfeiture remedy. ${ }^{243}$

Applying the faithless servant doctrine to sexual misconduct like Weinstein's also dovetails with much of the research regarding the best ways for changing workplace culture. ${ }^{244}$ First, disgorging compensation from a company's fiduciaries unquestionably models a "serious, sober approach" to addressing workplace harassment ${ }^{245}$ since most individuals would view the loss of some or all of their compensation as a grave indication of wrongdoing. Unlike empty statements of regret or consternation that may be issued by a company or its board, requiring the forfeiture of compensation paid to a disloyal worker demonstrates how seriously a company takes such wrongdoing. Similarly, such a loss of compensation undoubtedly constitutes a "concrete negative ramification" for this individual's misbehavior. ${ }^{246}$ Indeed, in Weinstein's case, an application of the faithless servant doctrine would lead to the disgorgement of millions of dollars, particularly if the court took into account such benefits as Weinstein's lush travel budget and backend revenue deals on his films. ${ }^{247}$ This seems particularly important where, as noted above, Weinstein may not otherwise personally experience direct financial consequences for his wrongdoing, given that the bulk of the civil claims against him seem likely to settle and will likely be covered in full by the Weinstein Company's insurance providers. ${ }^{248}$ Finally, in its own way, applying disgorgement principles to these situations could "alter[] the power structure" within the organization as a whole ${ }^{249}$ not necessarily by increasing the representation of women within the organization, but perhaps by stripping power (financial power, at least) from those whose conduct warrants such a relegation. If there is any truth to the mantra that "money is power," then using the faithless servant doctrine to disgorge funds from powerful harassers like Weinstein could at a minimum shake up the hierarchy within the organization.

Even when applying the specific criteria for disgorgement set forth in Kaye v. Rosefielde, forfeiture of at least some of Weinstein's compensation seems to

242. Hemel \& Lund I, supra note 32 (quotation marks omitted).

243. Id. (noting that directors and officers breach their fiduciary duties when they "act in bad faith for a purpose other than advancing the best interests of the company") (quotation marks omitted).

244. See supra $\S$ II.B.

245. See supra $\S$ II.B.1.

246. See supra $\S$ II.B.2.

247. See supra notes 47, 50-51 and accompanying text; infra § III.D.

248. See supra note 52 and accompanying text.

249. See supra $\S$ II.B.3. 
be a possible remedy. ${ }^{250}$ First, the Kaye court listed "the employee's degree of responsibility and level of compensation." 251 As one of the founders and cochairmen of the Weinstein Company, ${ }^{252}$ Harvey Weinstein enjoyed virtually limitless power within the organization, and his compensation of over $\$ 3,000,000$ per year almost certainly dwarfed that of most (if not all) other individuals in the organization. ${ }^{253}$ Second, the Kaye court identified as a factor "the number of acts of disloyalty." ${ }^{254}$ Weinstein's disloyalty infused virtually all that he did, encompassing his interactions with a vast array of players across the entertainment industry, from mega-stars to unknown interns. ${ }^{255}$ Indeed, with dozens of women already having publicly come forward to accuse Weinstein of assault, harassment, and rape (among other charges), ${ }^{256}$ and perhaps countless others who have not yet come forward or been identified publicly, ${ }^{257}$ a court readily could assume that Weinstein engaged in numerous acts of disloyalty.

The Kaye court further identified "the extent to which those acts placed the employer's business in jeopardy" as a criterion to consider when contemplating forfeiture. ${ }^{258}$ Once again, this factor weighs heavily in favor of disgorging Weinstein's compensation. While one could argue that, in the short term, Weinstein's behavior might have created advantages for his companies in the

250. 121 A.3d 862, 874 (N.J. 2015). Admittedly, Kaye itself may be of minimal precedential value in any existing litigation involving Weinstein. As previously noted, Weinstein reportedly reached a tentative settlement on the bulk of the civil claims against him, see supra note 52, and it is unclear whether any remaining civil claims will be litigated in a jurisdiction governed by Kaye. (For example, the actress Ashley Judd, who declined to join the settlement, brought her suit in a California federal court. See Corky Siemaszko, Ashley Judd Goes It Alone, Says She is Not Settling with Hollywood Honcho Harvey Weinstein, NBC News (May 24, 2019), https://www.nbcnews.com/news/us-news/ashley-judd-goes-italone-says-she-not-settling-hollywood-n1010141 [https://perma.cc/P4RH-W8FC]. Additional cases against Weinstein - both pending and resolved - are criminal in nature, see supra note 36 and therefore also not bound by the Kaye decision. Nonetheless, the rationale of Kaye may prove to be helpful guidance for courts considering this novel approach.

251. Kaye, 121 A.3d at 874.

252. See Farrow, supra note 1.

253. See Dade Hayes \& Dawn C. Chmielewski, Harvey Weinstein's Salary, Perks and Code of Conduct: Read His Employment Contract, DEADLINE (June 7, 2018), https://deadline.com/2018/06/harvey-weinstein-salary-perks-code-of-conduct-employment-contract1202405670/ [https://perma.cc/D5QE-TK87]. Weinstein's most recent contract with the Weinstein Company - a three-year agreement that took effect in January 2016 - paid him a base salary of $\$ 2,626,275$ per year, with $\$ 500,000$ per year guaranteed for private air travel. $I d$. Weinstein also was contractually assured of flying first class in those instances when he did not fly private, and received an allowance for "a first-class car and a driver, limousine transportation and first class private business travel expenses, including hotel suites and per diems." Id.

254. Kaye, 121 A.3d at 874.

255. See generally Farrow, supra note 1; Kantor \& Twohey, supra note 1.

256. See supra notes 29-32 and accompanying text.

257. See EEOC Task Force Report, supra note 11, at 8-10 (noting widely divergent statistics when measuring percentage of women who have experienced sexual harassment); LaMagna I, supra note 7 (noting "the person targeted for harassment is the one that faces retaliation and being blackballed in their profession") (quotation marks omitted).

258. 121 A.3d at 874 . 
form of greater power and influence, ${ }^{259}$ the end result of his behavior unquestionably hurt the company-bringing terrible publicity and ultimately financial ruin. ${ }^{260}$ As discussed previously, within weeks of the scandal becoming public, one of the company's largest creditors purportedly demanded an immediate repayment of a $\$ 45$ million loan that it had made to the Weinstein Company, ${ }^{261}$ and other longstanding corporate partners immediately distanced themselves from the company. ${ }^{262}$

Finally, the Kaye court cited "the degree of planning to undermine the employer that is undertaken by the employee" as a factor in determining whether disgorgement is appropriate. ${ }^{263}$ Countless witnesses have made clear that Weinstein's indiscretions were not isolated instances of spontaneous poor judgment, but rather involved great degrees of premeditation. ${ }^{264}$ Weinstein repeatedly deputized countless others within the Weinstein Company to facilitate his sexual misconduct. ${ }^{265} \mathrm{In}$ addition, Weinstein himself appears to have engaged in a concerted attempt to cover up his illegal behavior, working with his lawyers and public relations team to "conduct[] a decades-long campaign to suppress these stories." 266

Looking even more broadly at the philosophical underpinnings of compensation disgorgement, Weinstein's conduct falls squarely within the remedial goals of this doctrine. Compensation disgorgement (whether in the form of the faithless servant doctrine or operating under another label) is an equitable, restitutionary remedy ${ }^{267}$ As already noted, restitution differs from the legal remedy of damages in that, while damages aim to lessen or eliminate the

259. See supra note 5 and accompanying text (citing Oscar host's joke regarding actresses "pretending" to be attracted to Weinstein); see also Kantor \& Twohey, supra note 1 (describing movies as Weinstein's "private leverage" with female actresses and others); Vongkiatkajorn, supra note 30 (asserting that "[d]espite Weinstein's predatory behavior, he continued to make money off [his victims'] work").

260. See supra notes 38-46 and accompanying text.

261. See Hemel \& Lund I, supra note 32 .

262. See id.

263. Kaye, 121 A.3d at 874 . Notably, the Kaye court did not elaborate regarding the specificity of intent by the employee that is required to trigger disgorgement, i.e., whether the employee must actually intend to harm the employer vs. simply intend to engage in the activity that happens to result in harm. See id.

264. See, e.g., Farrow, supra note 1 (quoting one executive who worked for Weinstein for many years, observing that “[ $[\mathrm{t}] \mathrm{his}$ wasn't a one-off. This wasn't a period of time . . This was ongoing predatory behavior toward women - whether they consented or not") (internal quotations omitted); see also Kantor \& Twohey, supra note 1.

265. See Farrow, supra note 1; Kantor \& Twohey, supra note 1.

266. Farrow, supra note 1 (detailing the role that Weinstein's staff often played in facilitating and then covering up these encounters); see also Kantor \& Twohey, supra note 1 (discussing the "code of silence" enforced by Weinstein, holding Weinstein Company employees to contracts promising that "they will not criticize [the company] or its leaders in a way that could harm [the company's] business reputation or any employee's personal reputation") (internal quotations omitted).

267. John C. Kairis, Disgorgement of Compensation Paid to Directors During the Time They Were Grossly Negligent: An Available But Seldom Used Remedy, 13 DEL. L. REv. 1, 6, 8-9 (2011). 
harm that a plaintiff has suffered, ${ }^{268}$ restitution focuses on disgorging a defendant's wrongful gain. ${ }^{269}$ Thus, a court considering whether to apply disgorgement to Harvey Weinstein would not focus upon the extent to which the plaintiff (presumably, Weinstein's former employer, the Weinstein Company) may have suffered due to Weinstein's misconduct; rather, the court's attention would remain upon how Weinstein himself might wrongfully have gained from his misbehavior. ${ }^{270}$

Weinstein likely profited in a variety of ways from his behavior. Weinstein's power within the entertainment industry (before his fall, of course) was undisputed, with individuals who worked in all aspects of the business feeling compelled to kowtow to him in meetings, on movie sets, and even from the awards show stage. ${ }^{271}$ Yet while Weinstein's power enabled his sexual exploits, ${ }^{272}$ his sexual exploits also seemed to make him more powerful, giving him greater control over the careers of the women who complied —or not-with his overtures. ${ }^{273}$ In this way, the sexual power that Weinstein wrongfully asserted over his victims ultimately may have translated into his power within Hollywood more generally, in a sort of vicious cycle: While Weinstein's control within the industry functioned to silence his victims who feared retaliation if they spoke out against him, ${ }^{274}$ the aura of omnipotence and untouchable-ness that such silence created fostered the notion that Weinstein was to be worshipped, acceded to, and protected from reproach - a mentality that could not help but enhance his professional ability to dictate the who, when, and how of celebrity appearances in his films. He burnished his own star by proving that he quite literally could do whatever he wanted, to whomever he wanted, inevitably giving him greater power within the industry overall.

Weinstein's harsh mistreatment of those around him also may have bolstered his power on a more basic level, with the success of Weinstein's movies perhaps being more inextricably tied to his misbehavior. As at least one observer has noted, Weinstein and his brother Bob became known for their "alchemical skill at attracting top talent, squeezing maximum profit out of genre schlock, and reliably conjuring awards-season gold - seemingly on strength of

268. See, e.g., Michael P. Thomas et Al., CAlifornia Civil Practice Torts § 5:1 (2019); see also Dobbs, supra note $14, \S 3.1$.

269. See Kairis, supra note 267, at 6 (observing that disgorgement has functioned as "an equitable, rather than legal, remedy, designed to prevent the wrongdoer from profiting from the wrongdoing, rather than as a way to compensate the plaintiff for any losses").

270. As discussed in greater detail below, the Weinstein Company's own alleged complicity in Harvey Weinstein's wrongdoing complicates the analysis. See infra § III.D.

271. Farrow, supra note 1.

272. See supra note 241 and accompanying text; Farrow, supra note 1 (quoting one victim of Weinstein saying "[t]he type of control he exerted - it was very real ... Even just his presence was intimidating"); Kantor \& Twohey, supra note 1 (observing that "movies were ... his private leverage").

273. See generally Farrow, supra note 1 (detailing Weinstein's offers to aid the careers of women who complied with his sexual requests and his alleged retaliation against actresses who refused his advances); Kantor \& Twohey, supra note 1 (discussing same).

274. See generally Farrow, supra note 1; Kantor \& Twohey, supra note 1. 
the brothers' brash personalities alone." ${ }^{275}$ Perhaps Weinstein's need to harass and intimidate became such a part of his modus operandi that, had he suddenly and magically morphed into a kind and gentle Beta-male, his very brand (and his ability to execute upon that brand) would have suffered. ${ }^{276}$ Thus, while Weinstein may not have "benefitted" from his sexual misconduct as directly or concretely as the executive who absconds with his employer's clients or the employee who embezzles his employer's funds, Weinstein did arguably gain—-both personally and professionally - from his harassing behavior.

As conventional tools for addressing sexual harassment at work have proven fairly ineffective in combating this misbehavior, perhaps the more novel faithless servant doctrine and other compensation forfeiture tools can serve as a more successful way to alter the workplace culture. Moving beyond mere compensatory damages to apply compensation disgorgement to a wrongdoer like Weinstein might represent a more powerful approach, going beyond simply making a plaintiff whole with respect to the wrongs involved in a particular situation and instead deterring misbehavior in a broader manner by making that misbehavior unprofitable for the wrongdoer. ${ }^{277}$ Even in those jurisdictions that apply the faithless servant doctrine in its most limited form by requiring proof of harm to the employer and/or some connection between the employee's wrongful

275. See Chris Lee, Wait, How Is The Weinstein Company Worth Nearly \$500 Million?, New York: VUltuRE (Jan. 5, 2018), https://www.vulture.com/2018/01/how-is-the-weinstein-company-worthnearly-usd500-million.html [https://perma.cc/PLD2-CSJY]; Farrow, supra note 1 (observing that Weinstein "combined a keen eye for promising scripts, directors, and actors with a bullying, even threatening, style of doing business, inspiring both fear and gratitude").

276. Many thanks to my colleague, Daniel Yeager, for suggesting this interesting perspective regarding Weinstein's misconduct. Notably, this idea that Weinstein's misbehavior has served as some essential component of the success of his films has left countless members of the entertainment industry and the public conflicted about whether they should continue to enjoy his movies. As one entertainment industry writer and editor observed, "I have a very hard time being able to separate the art from the artist. I know that lying underneath whatever 'genius' is there, there's something so much worse and it's something that hurts women. How can anyone derive joy or entertainment from that?" Stahler, supra note 51.

277. Notably, in addition to sending a more powerful message to workplace wrongdoers than simply calculating compensatory damages, compensation disgorgement often will be much easier for plaintiffs to prove. Proving the compensatory damages caused by an employee's breach implicates a host of remedial hurdles: Plaintiffs must establish that the fiduciary's wrongdoing both directly and proximately caused any damages that the employer may have suffered. See Dobbs, supra note 14, § 3.4; Carroll \& Weida, supra note 197 (explaining that usual remedy for breach of fiduciary duty would be consistent with a tort remedy, requiring courts to look at the "amount of loss actually caused by the misconduct"). Employers also must establish that any harm suffered by the company due to the fiduciary's misconduct was specifically foreseeable. See Dobbs, supra note 14, § 3.4. Employers further must prove their damages to a reasonable degree of certainty, see id., something that can be difficult to do when grappling with breaches of loyalty that can have inexact and/or reverberating harms such as bad publicity, loss of goodwill, and loss of business opportunities. By applying the faithless servant doctrine or comparable forfeiture doctrines, however, employers can avoid these calculation problems, as courts fairly easily can establish the amount of compensation that a breaching fiduciary earned during a specified period of breach. See RESTATEMENT (THIRD) OF AGENCY $\S 801 \mathrm{cmt} . d$ (AM. LAW INST. 2006) ("Forfeiture may be the only available remedy when it is difficult to prove that harm to a principal resulted from the agent's breach or when the agent realizes no profit through the breach. In many cases, forfeiture enables a remedy to be determined at a much lower cost to litigants."). 
conduct and his or her job duties, ${ }^{278}$ much workplace sexual harassment likely will satisfy this requirement - particularly when practiced at a scale such as that shown by Harvey Weinstein. Where policies and training and temperate guidance all fail to discourage sexual harassment in the workplace, the best solution may be to hit bad actors where it hurts — in their pocketbooks.

\section{But Who Gets Weinstein's Salary? When the Faithless Servant Works for a Culpable Master}

In most (if not all) of the cases discussed above, requiring a breaching fiduciary to forfeit his or her compensation would seem to achieve equitable results due to the fiduciary's failure properly to serve his or her innocent master. Courts may take a different view, however, where the master/employer does not inhabit such an innocent role, but rather shares some culpability with the breaching employee. How can a court permit an employer to reap the financial benefits of recouping some or all of an employee's compensation when the employer itself countenanced - and perhaps even joined in - the conduct forming the basis of the fiduciary's breach? A court contemplating whether to apply forfeiture principles to Harvey Weinstein's compensation might well confront precisely this predicament.

In the weeks and months after the Weinstein story broke, various questions arose regarding what involvement, if any, the Weinstein Company had in Harvey Weinstein's misconduct. The Weinstein Company Board of Directors initially denied any knowledge regarding Weinstein's misconduct, claiming to be "shocked and dismayed" by these revelations ${ }^{279}$ and asserting that the charges "came as 'an utter surprise' to [the Board]." ${ }^{280}$ However, many outsiders remain skeptical about this alleged lack of awareness, pointing to settlement agreements which were reported to the Board and which would have been part of the metric considered in renewing Weinstein's most recent contract in 2015. ${ }^{281}$ In fact, Weinstein is purported to have settled harassment claims with at least eight women during a roughly thirty-year period ${ }^{282}$ - settlements that presumably would be disclosed to the Board of Directors. ${ }^{283}$ This has led an attorney for one accuser to argue that "executives must have long been on notice of [Weinstein's] behavior, based on the decades-long history of allegations and confidential settlements now being made public." 284

278. See supra notes 197-216 and accompanying text.

279. Faughnder et al., supra note 33 (quotation marks omitted).

280. Hemel \& Lund I, supra note 32.

281. See id.; Faughnder et al., supra note 33.

282. See Kantor \& Twohey, supra note 1.

283. See Hemel \& Lund I, supra note 32 (citing reports that the Board was informed of at least three confidential settlements between Weinstein and his accusers); see also id. (referring to one board member's claim that "he knew about multiple settlements but had thought they were being used to conceal consensual affairs").

284. Faughnder et al., supra note 33. 
The New York Times article that exposed Weinstein's misconduct reinforces this view, asserting that as early as 2015, several Weinstein Company board members (including Harvey Weinstein's brother and longtime business partner, Bob) were alarmed about the allegations of harassment against Weinstein, but ultimately "were assured there was no reason to investigate."285 Moreover, Weinstein's most recent contract is purported to have explicitly addressed the potential for future claims of misconduct against Weinstein, requiring Weinstein to reimburse the Weinstein Company for any settlements or judgments arising out of his misconduct and mandating additional payments to the Weinstein Company for each instance of misconduct. ${ }^{286}$ Based on such evidence, at least one scholar has suggested that the Weinstein Company's Board of Directors itself might be liable for breaching its fiduciary duty to investors for "exposing the company to unreasonable financial risk, whether negligently or knowingly."287 Thus, while various claims against the Weinstein Company and officers were dismissed in April 2019, ${ }^{288}$ many still believe that the company at best ignored the multitude of obvious danger signs, and at worst actively facilitated the misbehavior and its subsequent cover-up. ${ }^{289}$

Further adding to the possibility that the company itself might share responsibility for Weinstein's actions is the tremendous gain that the Weinstein Company accrued, at least indirectly, from Weinstein's misbehavior. As previously discussed, Weinstein's bullying and harassing conduct not only victimized female actresses and others in the entertainment industry; it also gave Weinstein greater power within the business, thus aiding him in his quest to dominate the industry, secure the work of any actress that he desired, and control how such actresses operated both on and off the set. ${ }^{290}$ While such powerhoarding benefitted Weinstein personally in various ways (sexual and otherwise), ${ }^{291}$ it undoubtedly garnered substantial benefits for the Weinstein Company as well, in the form of more successful movies with bigger stars and greater market dominance. ${ }^{292}$ While much public attention has been focused on the dire financial consequences for the Weinstein Company in the wake of the

285. Kantor \& Twohey, supra note 1.

286. Faughnder et al., supra note 33.

287. Hemel \& Lund I, supra note 32. At least one law firm has claimed to be actively "investigating potential fiduciary violations by TWC directors," soliciting information (and potential clients?) with respect to any such breach by the company. See Hagens Bergman Sobol Shapiro LLP, Weinstein Company Investor Alert: Hagens Bergman Investigating Potential Fiduciary Violations by TWC Directors, CISION PR NEwSWIRE (Oct. 16, 2017), https:/www.prnewswire.com/news-releases/weinstein-companyinvestor-alert-hagens-berman-investigating-potential-fiduciary-violations-by-twc-directors-

300537631.html [https://perma.cc/YFZ2-JVDU].

288. See supra note 42 and accompanying text.

289. See Vongkiatkajorn, supra note 30; FORBES, supra note 41 (noting that "[i]f what these women say is true, and The Weinstein Company and others went to great lengths to cover up Harvey's misdeeds and hush his accusers, this [RICO] case, unless settled, will most likely see its day in court").

290. See supra notes 241,272 and accompanying text.

291. See id.

292. See supra notes $272-76$ and associated text. 
scandal, for years the Weinstein Company flourished as at least an indirect result of Harvey Weinstein's misbehavior.

Concerns therefore may arise in applying traditional compensation forfeiture principles to Harvey Weinstein, in that such disgorgement would allow a possibly culpable master (the Weinstein Company) to reap significant financial benefits from its servant's misbehavior. Accordingly, a more sensible application of forfeiture to this matter might allow shareholders - or, perhaps, even victims of Weinstein's misconduct - to receive any compensation that ultimately is disgorged from Weinstein. Reaching such a legal result presents various difficulties, however. For example, it is unclear how any such legal action might be initiated. While a company's board of directors may bring a breach of fiduciary duty claim against a disloyal officer, ${ }^{293}$ to date, no board member has brought such an action against Weinstein, and no board member has indicated a likelihood of doing so. Indeed, with many of the claims against Weinstein and the Weinstein Company now having either been dismissed or tentatively settled, likely at the Weinstein Company's insurance carriers' expense, ${ }^{294}$ there seems to be little incentive for any board member to sue.

In the absence of a traditional breach of fiduciary duty claim, shareholders could pursue a "derivative action"- a lawsuit brought by shareholders on behalf of the company. ${ }^{295}$ Essentially, shareholders would stand in the shoes of the Weinstein Company Board to seek compensation from Weinstein on behalf of the company. Such derivative lawsuits impose a high standard on plaintiffs, however: A plaintiff first must demand that the corporation itself bring suit, something that seems unlikely to happen. ${ }^{296}$ Moreover, if the corporation refuses such a demand, the plaintiff must prove that the corporate directors could not have exercised "independent and disinterested business judgment" in their decision not to sue. ${ }^{297}$ In applying this "business judgment rule" to a corporation's decision not to sue, courts have made clear that "the board of directors is presumed to be disinterested and to have acted on an informed basis, in good faith, and in the honest belief that the action taken was in the best interests of the corporation. ${ }^{298}$ Accordingly, a board's decisions-including the decision not to sue - "will not be disturbed by a court if [it] can be attributed to

293. See Hemel \& Lund I, supra note 32 (observing that breach of fiduciary duty claims against a company's officers generally must be initiated by the company itself, rather than by disgruntled shareholders or other outsiders).

294. See supra note 52 and accompanying text.

295. See Richard D. Freer \& Douglass K. Moll, Principles of Business Organizations 476 (2013) (noting that shareholders may bring derivative actions when Board members themselves have breached their duties of care and/or loyalty); Hemel \& Lund I, supra note 32.

296. See Freer \& Moll, supra note 295, at 484.

297. See Hemel \& Lund I, supra note 32; Michael P. Dooley \& E. Norman Veasey, The Role of the Board in Derivative Litigation: Delaware Law and the Current ALI Proposals Compared, 44 BUS. LAW 503, 504-05 (1989).

298. Dooley \& Veasey, supra note 297, at 504-05 (citations omitted). 
any rational business purpose." ${ }^{299}$ Thus, so long as the Weinstein Company Board could demonstrate that its decision not to pursue legal action against Weinstein stemmed from any rational business reason, a shareholder derivative action against the Weinstein Company would seem unlikely to succeed.

In some instances, however, courts have excused plaintiffs from complying with this demand requirement if the plaintiff can show that such a demand would be "futile"-for example, by showing that directors would not be willing to act on a demand because of a conflict of interest or because the board itself bears some liability for the wrong in question. ${ }^{300}$ Such circumstances sometimes give rise to Caremark claims (named after a 1996 case involving allegations of fraud at a company bearing the same name). ${ }^{301}$ In Caremark claims, investors assert that the directors of a company breached their fiduciary duties by causing or permitting the company to break the law, or by failing to oversee a monitoring system that would ensure the company's compliance with the law. ${ }^{302}$ In other words, Caremark claims place liability on the board itself for failing to act in the face of "red flags" that "would make a reasonable person - who has the duty to advance the best interests of the company-take action and avoid further harm to the company. ..." ${ }^{303}$ In the context of the Weinstein Company, shareholders would allege that board members of the Weinstein Company breached their fiduciary duties by failing to properly monitor Weinstein, and that board members' own potential liability now prevents them from exercising "independent and disinterested judgment" in deciding whether to sue Weinstein themselves. ${ }^{304}$

Given the anecdotal evidence regarding the Weinstein Company Board's awareness of and failure to respond to Weinstein's ongoing misdeeds, ${ }^{305}$ a Caremark claim at first blush seems to represent a plausible approach. Caremark claims, however, also present significant hurdles for potential plaintiffs; only a showing of "sustained or systematic failure of the board to exercise oversightsuch as an utter failure to attempt to assure a reasonable information and reporting system exists - will establish the lack of good faith that is a necessary condition to liability." ${ }^{306}$ Delaware courts interpreting Caremark have held that

299. Id. at 505 (citation and internal quotations omitted).

300. See D. Gordon Smith \& Cynthia A. Williams, Business Organizations: Cases, Problems, AND CASE StUdies 518-19 (Wolters Kluwer ed., 4th ed. 2019).

301. In re Caremark Int'l Inc., 698 A.2d 959 (Del. Ch. 1996); see R. FrANKLIN BALOTTI \& JESSE A. FinKelstein, Delaware LaW OF CORPoRATIONS \& Business ORGANIZATIONS § 4.16 (3d ed. 1998); Hemel \& Lund I, supra note 32; Ted Johnson, Weinstein Scandal Triggers Questions of Corporate Liability and Even Complicity, VARIETY (Oct. 25, 2017), https://variety.com/2017/biz/news/harveyweinstein-sexual-harassment-corporate-liability-21st-century-fox-1202598683/ [https://perma.cc/NP9CPBW4].

302. Caremark, 698 A.2d at 970; see also BALOTTI \& FinKELSTEIN, supra note 301, § 4.16; Hemel \& Lund I, supra note 32; Johnson, supra note 301.

303. Johnson, supra note 301.

304. Hemel \& Lund I, supra note 32 (citations omitted).

305. See supra notes $281-87$ and accompanying text.

306. Id. at 971. 
this high standard may be met when "red flags ... are either waved in one's face or displayed so that they are visible to the careful observer." ${ }^{307}$ Perhaps Harvey Weinstein's three decades of workplace sexual misconduct-misconduct so blatant that it became the entertainment industry's worst kept secret ${ }^{308}$ - might meet this high standard, thus allowing this claim to serve as a vehicle for investors to get relief.

Corporate law experts can debate the best vehicle for finding liability against Weinstein and/or the Weinstein Company Board, based upon their collective misconduct. The more intriguing question, however, remains whether the proper remedy for any such claim might involve applying the faithless servant doctrine or a similar compensation forfeiture tool to disgorge Weinstein's compensation during the period in which he breached his fiduciary duties —and presumably to do so in a way that ensures that the Weinstein Company itself does not reap the financial benefits of such disgorgement. Should disgorgement principles be applied to Weinstein's compensation, any funds collected should be directed to the shareholders whose economic interest in the company has been decimated, or perhaps to Weinstein's victims whose lives were negatively impacted by his misconduct. ${ }^{309}$ Applying compensation disgorgement to predators like Harvey Weinstein provides companies with a powerful tool not only to demonstrate that egregious sexual misconduct negates any value that the misbehaving employee otherwise brought to the company, but also to communicate to their employees and to the public at large that their workplace culture will not tolerate such misbehavior.

\section{CONCLUSION}

More than three decades after the U.S. Supreme Court first deemed workplace sexual harassment unlawful under Title VII of the Civil Rights Act of $1964,{ }^{310}$ employers, employees, academics and members of the public continue to puzzle over how to stem this tide of inappropriate sexual misconduct at work.

307. Hemel \& Lund I, supra note 32 (internal quotations and citation omitted).

308. See supra notes $281-90$ and accompanying text.

309. One possible idea might involve creating a trust to hold the disgorged funds for the benefit of Weinstein's victims. See Investor Bulletin: How Victims of Securities Law Violations May Recover Money, U.S. SECS. \& EXCH. COMM'N (June 21, 2018), https://www.sec.gov/oiea/investor-alertsbulletins/ib_recovermoney.html [https://perma.cc/966N-HEL6]. While such an idea is intriguing, it presents multiple difficulties, the resolution of which fall outside the scope of this paper. For example, should all victims of Weinstein's inappropriate conduct benefit from this fund, from those who "merely" endured tasteless comments from Weinstein to those who suffered from physical assaults and/or rapes? Must an individual serve as a named plaintiff and/or as part of a class action against Weinstein in order to collect from such a fund? What level of proof must one show in order to collect? Do all victims collect equal shares from such a fund, or should an administrator parcel out funds according to the degree of harm? Cf. Jill S. Chanen \& Margaret G. Tebo, Accounting for Lives: The 9/11 Victim Compensation Fund Worked. But What About Next Time?, ABA J. (Sept. 2007) (discussing complicated method employed by Special Master Kenneth Feinberg in individualizing awards from 9/11 Victim Compensation fund).

310. See Meritor Sav. Bank v. Vinson, 477 U.S. 57 (1986). 
The faithless servant doctrine and comparable compensation forfeiture tools represent one possible solution to this problem.

Research shows that reducing sexual harassment in a workplace requires more than just training, education, and pleas for good behavior. Instead, employers must find a way to alter the broader culture in the workplace. Employees must come to see sexual harassment as a substantial wrong - one that is simply not tolerated by their employer. Disgorging a wrongdoer's salary conveys this type of significant statement, not only to the employee whose compensation is disgorged, but also to the broader employee population. Perhaps this is why the Employment Law Alliance - one of the world's largest networks of labor and employment lawyers ${ }^{311}$ — described the faithless servant doctrine as a "'hulk'-like superhero," 312 one that "serves up justice with 'smashing' deterrent impact." 313 The court in Astra likewise emphasized the importance of the deterrent impact of this doctrine, observing that while "New York's forfeiture law has been described as harsh ...., the harshness of the remedy is precisely the point." 314 Engaging in the compensation forfeiture contemplated by the faithless servant doctrine and similar mechanisms conveys a clear message to workers regarding what type of behavior simply will not be tolerated in the workplace.

There likely is no perfect tool for entirely eliminating sexual harassment at work. Dynamics of power and gender will continue to shape how employees interact with one another, leading some to behave in a manner that includes egregious and potentially unlawful sexual conduct or advances. While neither the faithless servant doctrine nor other compensation forfeiture tools represent the magic bullet, they do represent a new possible approach —one that might make headway in this longstanding and vexing problem, if applied in a way that properly addresses potential employer misconduct as well.

311. See About Us, EMP's LAW ALL., https://www.ela.law/about_us [https://perma.cc/M88ALUDP] (last visited May 4, 2020).

312. Howard M. Miller, Employment Law's "Hulk"-Like Superhero-The Faithless Servant Doctrine-Just Got Stronger, EMP'T LAW ALL. (June 8, 2016), https://www.ela.law/firms/bsk/articles/employment-law-s-hulk-like-superhero-the-faithless-servantdoctrine-just-got-stronger [https://perma.cc/M88A-LUDP].

313. Id.

314. Astra USA, Inc. v. Bildman, 914 N.E.2d 36, 51-52 (citations and quotation marks omitted); see also Kaye v. Rosefielde, 121 A.3d 862, 873 (N.J. 2015) (reasoning that "disgorgement may also have a valuable deterrent effect because its availability signals agents that some adverse consequences will follow a breach of fiduciary duty" (citing RESTATEMENT (THIRD) OF AGENCY $\S 8.01 \mathrm{cmt}$. d (2005) (quotation marks omitted)); $c f$. Warren, supra note 142, at 1137 (discussing "equitable clawback" of compensation and observing that it serves a "prophylactic function, deterring financial misbehavior through the imposition of a risk of forfeiture that could far exceed the proceeds ... derived from the fiduciary's misconduct"). 